OECDpublishing

\title{
CROSS BORDER INVESTMENT BY STATE-OWNED ENTERPRISES
}

OECD SCIENCE, TECHNOLOGY AND INDUSTRY POLICY PAPERS

December 2020 No. 96 


\section{2 | CROSS-BORDER INVESTMENT BY STATE-OWNED ENTERPRISES}

This paper was approved and declassified by the OECD Steel Committee on 30 November 2020 and prepared for publication by the OECD Secretariat.

Note to Delegations:

This document is also available on O.N.E under the reference code:

DSTI/SC(2020)7/FINAL

This document, as well as any data and any map included herein, are without prejudice to the status of or sovereignty over any territory, to the delimitation of international frontiers and boundaries and to the name of any territory, city or area.

(C) $\operatorname{OECD}(2020)$

The use of this work, whether digital or print, is governed by the Terms and Conditions to be found at http://www.oecd.org/termsandconditions. 


\title{
Cross-border investment by state-owned enterprises
}

Valentina Burrai, Luciano Giua, Kateryna Perepechay

\begin{abstract}
The paper analyses data on state-owned enterprises as cross-border investors and takes a first step towards analysing their investment characteristics since 2000. It shows that the number of cross-border investments by state-owned enterprises was overall small, with most originating from the People's Republic of China (hereafter "China"), and suggests that the investment preferences of state-owned enterprises may fuel excess capacity in the steel sector. This is because state-owned enterprises display a preference for building new capacity over acquiring existing capacity when investing abroad, and a preference for investment destinations with volatile demand growth. Data also suggest that state-owned enterprises might be more likely to undertake domestic capacity closures after a crossborder investment, which is likely influenced by recent policies introduced to curb excess capacity in China. Conversely, the data offer insufficient evidence regarding the link between cross-border investment by state-owned enterprises and capacity outcomes in target jurisdictions.
\end{abstract}

Keywords: Steel, Competition, Industry and Entrepreneurship, Investment 


\section{Table of contents}

1. Introduction $\quad 7$

2. Framework conditions 9

2.1. Background 9

2.2. Policy initiatives encouraging cross-border investment 9

3. Data for analysing cross-border investment by state-owned enterprises 14

3.1. Identifying state-owned enterprises and their characteristics 14

3.2. Matching: identifying companies across data sets 17

$\begin{array}{ll}3.3 . & 17 \\ 3.4 & 17 \text { otes on ownership history }\end{array}$

3.4. Notes on ownership history 17

3.5. Types of cross-border investment 18

3.6. General remarks about the analysis $\quad 19$

3.7. General remarks about the analysis 19

4. Characteristics of cross-border investment and investors in the steel industry 20

4.1. General investment preferences 20

4.2. Cross-border investors 24

4.3. Cross-border investors 24

4.4. Cross-border investment destination $\quad 27$

5. Cross-border investment and capacity changes 30

5.1. Total capacity changes in the jurisdiction receiving the investment 30

5.2. Capacity changes in the jurisdiction originating the cross-border investment 32

5.3. The role of capacity change in China 33

5.4. Capacity changes at the firm level $\quad 34$

6. Drivers of cross-border investment 36

6.1. Demand growth in the target jurisdiction 36

6.2. Circumvention of trade remedies 38

6.3. Securing raw materials 39 
References 2

Annex A. The projects data set 2

Annex B. The merger-and-acquisition data set 2

Annex C. The plant-level-capacity data set 2

Annex D. Regions $\quad 2$

\section{FIGURES}

Figure 1. Installed steelmaking capacity by region and ownership, $2019 \quad 18$

Figure 2. Cross-border investment in steel $\quad 21$

Figure 3. Instances of completed investment in the steel sector $\quad 23$

Figure 4. Count of cross-border investors in merger-and-acquisition deals by origin $\quad 25$

Figure 5. Count of cross-border investors in greenfield projects by origin 27

$\begin{array}{lr}\text { Figure 6. Cross-border mergers and acquisitions by destination } & 28\end{array}$

Figure 7. Cross-border greenfield projects by destination $\quad 29$

Figure 8. Capacity changes in the target jurisdiction after a cross-border merger-and-acquisition deal 31

Figure 9. Capacity changes in the investor jurisdiction after a merger-and-acquisition deal 32

Figure 10. Destination of cross-border investment by investor ownership 37

Figure 11. Merger-and-acquisition investment counts by location on the value chain 40

Figure 12. Upstream and downstream counts of cross-border merger-and-acquisition investment 41

\section{TABLES}

Table 1. Domestic bias in greenfield investment projects by investor ownership 20

Table 2. Frequency of investment by type 2000-19 23

Table 3. Type of cross-border investment by investor ownership 2014-19 24

Table 4. Capacity changes in the investor jurisdiction, three years after a cross-border greenfield investment 33

Table 5. Capacity changes in the investor jurisdiction, one year after a cross-border merger and acquisition deal

Table 6. Capacity changes in the investor jurisdiction, one year after a cross-border greenfield investment

Table 7. Chinese cross-border investor capacity changes, two years after project announcement 35

Table 8. Cross-border merger-and-acquisition deals and trade remedies 38

$\begin{array}{ll}\text { Table 9. Cross-border greenfield projects and trade remedies } & 38\end{array}$ 


\section{Executive summary}

Anecdotal evidence suggests that cross-border investment by state-owned enterprises is on the rise and especially the international investment from the People's Republic of China, hereafter China, has attracted attention. This is (partially) due to recent policies by the Chinese government to consolidate steelmaking capacity domestically and to promote and facilitate the participation of state-owned firms in the Belt and Road Initiative. As crossborder investors, state-owned enterprises present two challenges to the global steel industry. First, state ownership may extend benefits to state-owned enterprises unavailable to their competitors, disrupting fair competition in the steel markets. Second, state-owned enterprises may display investment preferences that exacerbate excess capacity.

Based on novel data sets, this paper provides an update on the data work on state-owned enterprises as cross-border investors and lays a first brick in the analysis of their investment characteristics in the years 2000-19. The data work underpinning this project provides an almost global mapping of state ownership in the steel sector as of the year 2019, and the tools to associate information on state ownership with information on steelmaking capacity, steelmaking expansion plans, mergers and acquisitions, and on economic performance at the firm level.

The data gathered here show that for the period 2000-2019 the number of cross-border investments by state-owned enterprises was overall small. Additionally, state-owned crossborder investment originated most often in China. This should be borne in mind while considering the findings presented in this paper.

Data analysed in this paper suggest that investment preferences of state-owned enterprises (or their pursuit of legitimacy as cross-border investors) may promote the proliferation of excess capacity in the steel sector across borders. In particular, state-owned enterprises display a preference for building new capacity over acquiring existing capacity, and a preference for investment destinations characterised by volatile demand growth.

With regard to the link between cross-border investment by state-owned enterprises and capacity outcomes, data analysed here suggests that, in the aftermath of cross-border investment, state-owned enterprises undertake capacity closures at the firm level (considering all jurisdictions in which a firm has installed steelmaking capacity) more often than non-state-owned enterprises. The link is stronger for cross-border investment with investors from China where policies to control excess capacity in the steel sector led to capacity closures in the years since 2015. Conversely, the data analysed here offer insufficient evidence regarding the link between cross-border investment by state-owned enterprises and capacity outcomes in the jurisdictions targeted by the investment.

However, the analysis in this paper is only a first step in the discussion on the effects of cross-border investment by state-owned enterprises. Foremost, the results have to be interpreted with care and more work is needed in analysing the impact of international investment by state-owned enterprises on the steel industries at home and abroad and on global excess capacity. 


\section{Introduction}

Cross-border investment by state-owned enterprises plays an important role in the steel industry. Previous research has shown that cross-border investment projects by state-owned enterprises accounted for $17.4 \%$ (or $40 \mathrm{mmt}$ ) of the potential capacity additions through the investment projects active in 2019 (OECD, 2019, p. 10 $0_{[1]}$ ), and anecdotal evidence suggests that cross-border investment by state-owned enterprises may be a growing trend. At the same time evidence has emerged that state-owned enterprises in the steel sector experience weaker economic performance and higher indebtedness than private enterprises (Mattera and Silva, 2018, p. $4_{[2]}$ ), which raises questions about the motives of this investment. As their investment decisions may be informed by considerations other than market-based, concerns are increasingly raised that state-owned enterprises may contribute to overcapacity in the steel sector and compete unfairly as state backing may afford them undue advantages, harming their competitors (Watanabe, 2020, p. $29_{[3]}$ ). When stateowned enterprises invest across borders, such distortions may reverberate across those jurisdictions that host the investment (Kowalski and Rabaioli, 2017, p. 10 $0_{[4]}$ ).

The motives of state-owned enterprises to invest abroad are thus an area of concern as their business objectives may commit them to pursue aims that are not solely driven by market considerations. However, it is also possible that state-owned enterprises may act purely on commercial grounds in their decisions to invest abroad (OECD, 2016, pp. 53-54 $4_{[5]}$ ). Therefore, the objective of this study about state-owned enterprises as foreign investors is to identify differences between state-owned and non-state-owned enterprises as foreign investors, particularly along the dimension most salient to the steel industry: fair competition and excess capacity.

This paper empirically analyses cross-border investment patterns and characteristics in the global steel industry in the years between 2000 and 2019 and identifies a number of differences between state-owned and non-state-owned enterprises as cross-border investors. First, the results of this paper show that state-owned enterprises in the steel sector display different investment preferences than other enterprises. In particular, they have a relatively greater preference for greenfield investment (understood as the construction of new steelmaking capacity) and for upstream investment (defined as the acquisition of assets such as mines, located upstream of steelmaking in the industry value chain, see sections 4.1 and 6.3 respectively). This may point to differences in underlying investment drivers (for instance the pursuit of new markets and the securing of raw-materials supply) but it may also indicate a greater need for state-owned enterprises to legitimise their role as crossborder investors by avoiding contentious foreign takeovers in favour of employmentcreating new plants. In particular, securing long-term supply of raw materials and strengthening relations with other economies by creating new production facilities and employment opportunities may be of greater priority for state-owned enterprises compared to their private counterparts (Cuervo Cazurra et al., 2014[6]; Bass and Chakrabarty, 2014[7]).

A second difference relates to the destination of cross-border investment. Overall, target jurisdictions of investment by state-owned enterprises tend to have higher steel-demand volatility (sections 4.3 and 6.1), suggesting that state-owned enterprises are less risk-averse than other enterprises (Ren and Jack, 2015 ${ }_{[8]}$ ). In particular, cross-border investments by China (the largest foreign investor through state-owned enterprises in the global steel sector - see section 4.2), go predominantly to Southeast Asia and to a lesser extent Africa. This may relate to Chinese plans to build a maritime transport network and fund infrastructure development alongside it (section 2.2). As such, the results of this paper point to the possibility that cross-border investment by state-owned enterprises may be a possible foreign-policy tool (Deng, 2004 $\left.{ }_{[9]}\right)$. 
Third, some differences emerge about capacity outcomes. Compared to other firms, stateowned enterprises, particularly within China, were associated more strongly with capacity closures at the firm level in the aftermath of a cross-border deal (section 5.4). This suggests that state-owned enterprises may be a more diligent executor of government policies of capacity rationalisation and capacity export in that country (section 2.2). Additionally, the targeting of regions that are geopolitically relevant but have volatile demand growth may have implications for excess capacity. As greenfield investment is carried out in those economies, should their steel demand grow insufficiently to absorb the additional capacity, excess capacity may arise in those economies (Tham and Yeoh, 2020 ${ }_{[10]}$ ).

The report is structured as follows. Section 2. summarises the framework conditions regulating state-owned enterprises as cross-border investors. Section 3. provides an update on the novel data sets that support this research. The report then summarises (section 4. ) the characteristics of state-owned enterprises as foreign investors across two types of investment - the construction of new steelmaking plants and acquisitions of existing companies. The relationship between ownership status of the foreign investor and capacity outcomes at the jurisdiction and firm level following an investment is explored in section 5. Finally, the report explores differences between the drivers of cross-border investment for state-owned and non-state-owned enterprises. Drivers include pursuing market growth in the target jurisdiction (section 6.1), avoiding trade remedies against the jurisdiction of origin (section 6.2) and seeking raw material resources (section 6.3). Finally, the annexes provide a short description of the key data sets used. 


\section{Framework conditions}

\subsection{Background}

The increased presence of state-owned enterprises in international trade and investment has raised a number of concerns among policymakers and stakeholders involved in the relevant industries. These concerns relate to preferential treatment and government-granted advantages provided to state-owned enterprises, which are not available to their private competitors, as well as policy objectives that some state-owned enterprises may be tasked with by their governments (OECD, 2016 $\left.6_{[5]}\right)$.

The results of the OECD Business Survey on State Influence on Competition in International Markets conducted in 2014 demonstrated that ownership of an enterprise plays an important role when it comes to perceptions of preferential treatment of foreign competitors by their governments (Kowalski and Perepechay, $2015_{[11]}$ ). The insights from the business survey, in which responses from steel sector representatives were prominent, indicate that preferential treatment granted to foreign state-owned enterprises had an impact on respondents' sales both in the domestic and in foreign markets. When it comes to investment, more than one quarter of respondents indicated that their foreign investment was strongly harmed by the preferential treatment that foreign governments granted to their competitors, while a third of the respondents indicated that they were somewhat affected. ${ }^{1}$

\subsection{Policy initiatives encouraging cross-border investment}

Over the past years, the presence of state-owned enterprises has become more prominent in global markets and the cross-border effects of state-owned enterprises' activities remain an important policy issue. In the current context of excess capacity in the steel sector, a number of concerns have been raised about policy programmes and the associated support measures that have been put in place by some governments to support overseas investments by their domestic steelmaking enterprises. ${ }^{2}$ Of particular concern are policy developments in China, the biggest steelmaking economy and, as further analysis suggests, the home to large state-owned investors. ${ }^{3}$ The policy backdrop is defined by two initiatives: the process of reform of state-owned enterprises and the Supply Side Structural Reform started in December 2015.

Over the past years, the presence of state-owned enterprises has become more prominent in global markets and the cross-border effects of state-owned enterprises' activities remain an important policy issue. In the current context of excess capacity in the steel sector, a number of concerns have been raised about policy programmes and the associated support measures that have been put in place by some governments to support overseas investments by their domestic steelmaking enterprises. ${ }^{4}$ Of particular concern are policy developments in China, the biggest steelmaking economy and, as further analysis suggests, the home to large state-owned investors. ${ }^{5}$ The policy backdrop is defined by two initiatives: the process of reform of state-owned enterprises and the Supply Side Structural Reform started in December 2015.

In China's mixed economic system, the reform of state-owned enterprises has been a gradual and low-profile feature of economic management, often spurred by high indebtedness or the weak performance of state-owned enterprises (Garnaut, Song and Yao, 2006 , pp. 35, 37 $[12]$ ). Two features of the reforms have been most relevant for the steel industry in general and cross-border investment in particular: the trend towards larger stateowned enterprises, and the confirmation of state-owned enterprises as policy tools. The shift towards larger state-owned enterprises, which started in the 1990s with the policy of 
"keep the large and let the small go", meant that the state would retain control of the largest state-owned enterprises and would relinquish ownership, in part or in total, of the smaller firms (Garnaut, Song and Yao, 2006, pp. 38, 42, 44 $\left.{ }_{[12]}\right)$. The trend continued with the decision in 2006 to include steel among the so-called pillar industries. The state would maintain absolute or relative controlling stakes in companies operating in pillar industries. These stakes would be gradually reduced in privatisation processes. Additionally, stateowned enterprises would remain the largest corporate players in pillar industries, Moreover, state resources, particularly of a financial nature, would be preferentially directed to these firms. As such, state-owned enterprises could benefit from international mergers and acquisitions which another policy of the early 2000, the go global policy, made possible (Song, 2018, pp. 356-357 ${ }_{[13]}$ ). In 2015, reforms focused on the creation of national champions, very large state-owned enterprises formed by government-led mergers with the aim of eliminating inefficient or highly indebted firms, reducing corporate debt and eliminating duplicate investment. In the steel sector, an example of this process is given by the creation of BaoWu from the acquisition by Shanghai Baosteel Group of the highly indebted Wuhan Iron and Steel. Although state-owned enterprises were categorised into public (akin to utilities) and commercial (to be operated with market logic), both categories must be at the service of political goals such as the promotion of the Belt and Road Initiative (Song, 2018, p. 362 [13]).

The policy push for the creation of national (state-owned) champions coincided and reinforced a set of reforms launched from December 2015 onwards and known as Supply Side Structural Reforms. They were aimed at addressing overcapacity and over indebtedness in steel as well as in other industries, and at resolving the issue of so-called zombie enterprises - that is economically unviable firms kept in operations by the support of the government, particularly local government. The most consequential policy for the steel industry was the establishment of a target for steel capacity reduction, to be achieved by concentrating production, and promoting the closure of outdated, polluting or otherwise undesirable capacity by the newly formed industry champions (Boulter, 2018 [14]).

Against this backdrop, the Chinese government has introduced a number of initiatives encouraging and facilitating outward investment by its enterprises in the steel sector. In particular, China's 13th Five-Year Plan (2016-2020) encourages "more of China's equipment, technology, standards, and services to go global by engaging in international cooperation or production capacity equipment manufacturing through overseas investment project contracting, technology cooperation, equipment exporting, and other means, with a focus on industries such as steel." To support this objective the plan notes the need to improve services such as taxation, finance, insurance, investment and financing platforms, and risk assessment. ${ }^{6}$ Furthermore, the 2015 State Council Guiding Opinion on Promoting Cooperation in Production Capacity and Equipment Manufacturing provides additional details on how the go global strategy is to be implemented and specifies a variety of financial support measures that are available to the Chinese steelmaking companies to facilitate their investments in steel production projects in other economies such as fiscal and tax support policies, concessional loans, financial support through syndicated loans, export credits, and project financing, equity investment and export credit insurance. In the wake of the Council Guiding Opinion, some provincial and city governments have issued implementation policies and target as illustrated in Box 1. 


\section{Box 1. Chinese provincial policies}

To meet the objectives highlighted in the 2015 Guiding Opinions of the State Council and in the BRI, at least three provincial governments have drawn specific plans that support local steel enterprise to invest abroad and cooperate with foreign producers.

In 2016, the government of Heilongiiang province released a plan to promote external capacity cooperation for steel enterprises located in the "China-Mongolia-Russia Economic Corridor". The plan encourages local steel enterprises to carry out foreign cooperation in production capacity of steel and building materials, drive the export of equipment and engineering contracting, and expand the areas of overseas cooperation (Heilongjiang Province, 2016 ${ }_{[15]}$ ).

Also in 2016, the government of Liaoning province released the document "Advancing the implementation of industrial supply-side structural reforms" which encourages companies to actively reduce excess capacity through international capacity cooperation. The government supported enterprises with policies such as improving the non-performing loans verification policy and reducing and exempting relevant taxes and fees. The plan encourages provincial enterprises to operate on countries along the "Belt and Road" with good resource conditions, strong supporting capabilities, and large market potential to promote the export of excess capacity (Liaoning Provincial Industry and Information Department, 2016 [16] $)$.

In 2018, the government of Hebei province released the "Implementation Plan for International Capacity Cooperation of Iron and Steel Enterprises in Hebei Province". By providing comprehensive coordination services such as negotiation, cross-border investigations, foreign coordinated investment, policy support, foreign exchange management, and remittances services, the plan aims to support local iron and steel enterprises to carry out overseas investment, export equipment and technology overseas and expand international capacity cooperation (Hebei Development and Reform Commission, 2018 $\left.8_{[17]}\right)$. The plan promotes structural adjustment of the iron and steel industry and creates a new model for international capacity cooperation focused on greenfield investment, equity mergers and acquisitions, contracting operations and other methods to establish overseas production bases, acquire high-quality foreign assets, internationally renowned brands, $R \& D$ centres and marketing networks. The plan also sets a target for Hebei province's iron and steel enterprises to have an overseas production capacity of 12 million tons by the end of 2020 (Hebei Development and Reform Commission, 2018 $\left.{ }_{[17]}\right)$.

Note: Among others, local enterprises mentioned in the Heilongjang province policy are: Xilin Iron and Steel Group Co., Ltd., Shuangyashan Jianlong Steel Co., Ltd., and Beiman Special Steel Co., Ltd. Companies, CNBM Northern Cement Co., Ltd.

In April 2016, the People's Bank of China, the China Banking Regulatory Commission, the China Securities Regulatory Commission, and the Insurance Regulatory Commission published the Opinions on supporting the steel and coal industries to resolve overcapacity and achieve turnaround in development, which call policy and development finance institutions to intensify their financial support for eligible steel and coal enterprises in their international capacity cooperation using syndicated loans, export credits and project financing. The document also calls on commercial banks to give financing support to steel and coal enterprises when transferring capacity overseas and exploiting international 
markets under the principles of risk control and commercial sustainability. The enterprises are also encouraged to acquire loans by mortgaging their overseas assets, equity, mining rights and other rights and benefits. Domestic steel and coal enterprises are encouraged to work with countries alongside China's Belt and Road Initiative as well as key countries relevant for capacity cooperation by taking advantage of financial and investment platforms like the Silk and Road Fund (see also Box 2).

Anecdotally, these policy initiatives have contributed to an increase in cross-border investment by Chinese enterprises in recent years. In particular, the Association of Southeast Asian Nations region has become one of the main destinations for investment by Chinese steelmaking enterprises. ${ }^{7}$ The increasing number of such investments, however, raises important concerns. According to calculations made by the South East Asia Iron and Steel Institute (SEAISI), it would take about 20 years to absorb the capacities now being built if all currently planned projects come on stream. This shows that many of the currently proposed projects are expected to add capacity to a market which is already in an overcapacity situation, threatening the sustainability of the regional and global steel industry. $^{8}$

\section{Box 2. China's Belt and Road Initiative}

China's Belt and Road Initiative (BRI) launched in 2013 is a development strategy aiming to build connectivity and co-operation across six main economic corridors encompassing China and: Mongolia and Russia; Eurasian countries; Central and West Asia; Pakistan, Nepal, Bangladesh, Sri Lanka; and Indochina. BRI investment projects are estimated to add over USD 1 trillion of outward funding for foreign infrastructure over the 10-year period from 2017. Most of the funding for these projects come from state-directed development and commercial banks, although new vehicles, such as Silk Road Fund, have been formed to help with the financing.

As part of the BRI initiative, an objective was announced to move iron, steel and a few other industries to the BRI-participating economies. This objective was highlighted by the Premier of China, Li Keqiang at the 17th ASEAN conference in 2014: "After years of development, China now has a strong capacity in infrastructure development and Chinese equipment is of high quality. We encourage competitive Chinese producers of iron and steel, cement and plate glass, etc. to shift their operation to ASEAN countries to meet the local need of infrastructure development through investment, leasing and loan lending so as to achieve mutual benefit"

Source: OECD (2018), "The Belt and Road Initiative in the global trade, investment and finance landscape", in OECD Business and Finance Outlook 2018, OECD Publishing, Paris, https://doi.org/10.1787/bus fin out-2018-6-en.

More work is needed to collect systematic information on state support to outward investment in other jurisdictions originating cross-border investment in the steel sector. The policies considered at this stage had a vaguer or narrower focus than those put forward by the Chinese government. For instance, Qatar's development plan Qatar National Vision mentions the need for "Coordination with Gulf Cooperation Council States and with Arab Regional economic organisation to establish trade, investment and financial ties" and for a more diversified economy (Qatari General Secretariat for Development Planning, 2008 [18]). However, no specific provisions could be identified supporting outward investment by steel 
enterprises or in the field of steelmaking. Japan and Korea have policies in place focussed on securing the long-term supply of raw materials. Among other objectives, state-owned funding bodies (JOGMEC in Japan and KORES for Korea) offer financial and technical support to outward foreign investment by domestic firms investing in the development and exploitation of mining projects of a variety of raw materials, including some metals that may be used in steel alloys (Hatayama and Tahara, 2015, pp. $72-73_{[19]}$; KORES, n.d.[20]). 


\section{Data for analysing cross-border investment by state-owned enterprises}

This section aims to update the Steel Committee on the original and large data work that has underpinned research on state-owned enterprises, particularly as this stream of work is expected to continue in the PWB 2021-22.

Gathering insights on cross-border investment by state-owned enterprises requires data to be extracted from different novel data sets. It is important to provide an update on the data work to clarify what information can and cannot be accessed at different stages of the research, and to define the limits and caveats to an empirical study of state-owned enterprises' investment such as this one. It is also important to underline that investment in data preparation has broadened the range of topics that the Committee will be able to investigate and the range of methods that can be leveraged to investigate them.

To address questions about capacity changes and cross-border investment drivers, the data must allow for the identification of: i) a company and its ownership status over time and across jurisdictions; and ii) steelmaking plants owned by a company over time and across jurisdictions. ${ }^{9}$ As no single known data source contains all of the aforementioned information, the necessary data were compiled from primary and secondary research, and by leveraging four existing data sets. ${ }^{10}$

\subsection{Identifying state-owned enterprises and their characteristics}

The first critical task is the tagging of companies so that they can be identified as stateowned or not. This paper - like most previous studies analysing state-owned enterprises at the industry or economy-wide level ${ }^{11}$ - uses the criterion of $50 \%$ equity ownership to define state-owned enterprises. ${ }^{12}$ This choice was also dictated by practical considerations and as such does not imply a preference for the concept of state ownership over the very useful, if more elusive, concept of state control, as discussed in Box 3. As some firms may be state-controlled even if they are not owned by the state, firms are classified throughout the paper as either state-owned or non-state-owned.

Data on equity ownership are the most widely available. ${ }^{13}$ These data can be found in the Orbis data set, as well as in company reports or other publicly available documentation. Orbis reports ownership information through the concept of global ultimate owner, at the $25 \%$ and at the $50 \%$ levels of ownership. Global ultimate owners are firms or individuals at the end of the ownership chain holding directly or indirectly shares of more than $50 \%$ of the subsidiary (OECD, 2019, pp. 2, 10 [21]; Bureau van Dijk, n.d. $\left.{ }_{[22]}\right){ }^{14}$

Wherever possible, tagging was automated using Orbis fields of global ultimate owner. ${ }^{15}$ However, automation worked only for a relatively small subset of the data. ${ }^{16}$ For $92.2 \%$ of the entries in the projects data set - which describes investment in new steelmaking capacity at the global level - and $70.0 \%$ of the entries in the plant-level-capacity data set which describes plant-level steelmaking capacity in most of steelmaking economies - tags were researched on a case-by-case basis. ${ }^{17}$ This task therefore was as much about primary research as it was about data preparation.

Tagging has been completed for all companies located in those economies covered in the Secretariat's plant-level capacity database as of October 2020 and the investment project data sets, and for which sufficient information on ownership could be found. Stateownership tagging is outstanding for some Iranian companies and for companies in economies added to the plant-level capacity database after October $2020 .{ }^{18}$ 
Some additional tagging was attempted on the merger-and-acquisition data set. The first aim was to identify the position of the deal along the steel value chain. Data on greenfield projects by definition identify investment in new steelmaking capacity. ${ }^{19}$ The data on mergers and acquisitions are different as they identify deals to acquire targets along the steelmaking value chain. These include not only steelmakers but also miners (upstream) and finished steel producers (downstream). Tagging was carried out on this data set using a simple automatic method which searches for a set of keywords aimed at identifying a mining or re-rolling operation. In cases of ambiguity the tagging was dropped. ${ }^{20}$

The second aim was to identify deals in which non-steelmaking state-owned enterprises may offer financial support in a cross-border deal in the steel sector. Cross-border nonsteelmaking state-owned investors are identified by supplementing the pool of state-owned enterprises tagged in the OECD plant-level capacity data set with the list of firms identified as state-owned by Dealogic. ${ }^{21}$ Like the upstream-downstream tagging, also this tagging was based on primary and secondary Standard Industry Classification and Business Description available in Dealogic. ${ }^{22}$

Tagging has been completed for all companies located in those economies covered in the Secretariat's plant-level capacity database as of October 2020 and the investment project data sets, and for which sufficient information on ownership could be found. Stateownership tagging is outstanding for some Iranian companies and for companies in economies added to the plant-level capacity database after October $2020 .^{23}$

Some additional tagging was attempted on the merger-and-acquisition data set. The first aim was to identify the position of the deal along the steel value chain. Data on greenfield projects by definition identify investment in new steelmaking capacity. ${ }^{24}$ The data on mergers and acquisitions are different as they identify deals to acquire targets along the steelmaking value chain. These include not only steelmakers but also miners (upstream) and finished steel producers (downstream). Tagging was carried out on this data set using a simple automatic method which searches for a set of keywords aimed at identifying a mining or re-rolling operation. In cases of ambiguity the tagging was dropped. ${ }^{25}$

The second aim was to identify deals in which non-steelmaking state-owned enterprises may offer financial support in a cross-border deal in the steel sector. Cross-border nonsteelmaking state-owned investors are identified by supplementing the pool of state-owned enterprises tagged in the OECD plant-level capacity data set with the list of firms identified as state-owned by Dealogic. ${ }^{26}$ Like the upstream-downstream tagging, also this tagging was based on primary and secondary Standard Industry Classification and Business Description available in Dealogic. ${ }^{27}$

\section{Box 3. Defining and operationalising state-owned enterprises}

\section{Definitions}

Definitions of state-owned enterprises vary across jurisdictions. In the OECD Guidelines on Corporate Governance of State-Owned Enterprises (OECD, 2015, pp. 14$\left.16_{[23]}\right)$, an internationally agreed definition is provided. By that definition:

[...] any corporate entity recognised by national law as an enterprise, and in which the state exercises ownership, should be considered as an SOE [stateowned enterprise]. This includes joint stock companies, limited liability companies and partnerships limited by shares. Moreover statutory corporations, with their legal personality established through specific 
legislation, should be considered as SOEs if their purpose and activities, or

parts of their activities, are of a largely economic nature.

Further, the definition differentiates between ownership and control. Ownership is defined as the state's ultimate holding (that is direct or indirect) of the majority of voting shares or [the state's] otherwise exercising an equivalent degree of control. The threshold to define ownership is therefore $50 \%$ plus one share. The Guidelines also establish a lower bound.

Entities in which the government holds equity stakes of less than ten percent that do not confer control and do not necessarily imply a long-term interest in the target company, held indirectly via independent asset managers such as pension funds, would also not be considered as SOEs.

Therefore, when ultimate state-ownership falls between $10 \%$ and $50 \%$ a company is considered equivalent to state-owned if the state exercises over it an equivalent degree of control. Whether the degree of control conferred by minority ultimate ownership is equivalent to that conferred by majority ownership must be assessed.

\begin{abstract}
For example whether a "golden share" amounts to control depends on the extent of the powers it confers on the state. Also, minority ownership by the state can be considered as covered by the Guidelines if corporate or shareholding structures confer effective controlling influence on the state (e.g. through shareholders' agreements).
\end{abstract}

\title{
Operationalisations
}

The operationalisation of state ownership is feasible as both diplomatic agreement and data exist about majority ownership. Both diplomatic agreement and data availability become more problematic when assessing the concept of equivalent degree of control.

The identification of state-controlled companies is highly desirable as minority ownership may conceal de facto government control. The task is however resource intensive. As data on a $10 \%$ ownership threshold are not systematically available for example in the Orbis database, assessing the degree of control requires data collection on ultimate ownership at that level as well as data collection on golden shares and shareholders' agreements. Additionally, deploying the concept of control requires the development of an agreeable methodology for interpreting the data and tagging the firms.

While desirable, the identification of state control as per OECD Guidelines may only be achievable in studies with a very small number of observations. To the knowledge of the Secretariat, no quantitative studies have been carried out that operationalise the concept of state control described above. Sometimes, thresholds other than $10 \%$ are used to indicate state control (Molnar and $\mathrm{Lu}, 2019$, pp. 14, 41 ${ }_{\text {[24] }}$ ) or in conjunction with ownership to illuminate differences between the two categories of majority and minority ownership (IMF, 2020, pp. 47, 57 [25]). Even in studies with a small number of firms, alternative thresholds are deployed (OECD, 2019, pp. 49-50[26]). State ownership at the $50 \%$ threshold is therefore routinely used in quantitative studies, see e.g. (OECD, 2019, pp. $90-94_{[27]}$; OECD, 2020, p. $4_{[28]}$; IMF, 2020 [25]). The present study adopts a definition of state-ownership as ultimate (direct and indirect) ownership at the $50 \%$ threshold.

Note: See Note on Definition Used in Output Area 3PWB 


\subsection{Matching: identifying companies across data sets}

Once information is available on the status of a steel firm, it is recorded against the ID of the firms listed in the plant-level-capacity data set. From there, that information needs to be seamlessly recalled across all relevant data sets, so that a consistent definition of ownership may be applied to all questions surrounding cross-border investment. To achieve this, it is necessary to match company names across different data sets. ${ }^{28}$ Not surprisingly, name matching is resource intensive as company names may vary to a significant extent, especially when they are transliterated from non-Latin scripts, which may result in ranges of different transliterations. Additionally, company names may change over time and they may therefore appear differently in different data sets, depending on when the information was recorded.

Matching has been completed in the (smaller) projects data set. In the (larger) merger-andacquisition data set, matching has been completed for all jurisdictions included in the plantlevel capacity data set as of October 2020.

\subsection{Notes on ownership history}

Once information is available on the status of a steel firm, it is recorded against the ID of the firms listed in the plant-level-capacity data set. From there, that information needs to be seamlessly recalled across all relevant data sets, so that a consistent definition of ownership may be applied to all questions surrounding cross-border investment. To achieve this, it is necessary to match company names across different data sets. ${ }^{29}$ Not surprisingly, name matching is resource intensive as company names may vary to a significant extent, especially when they are transliterated from non-Latin scripts, which may result in ranges of different transliterations. Additionally, company names may change over time and they may therefore appear differently in different data sets, depending on when the information was recorded.

Matching has been completed in the (smaller) projects data set. In the (larger) merger-andacquisition data set, matching has been completed for all jurisdictions included in the plantlevel capacity data set as of October 2020.

\subsection{Notes on ownership history}

Another useful data compilation task is the construction of an ownership history at the company level. Data available at this stage provide information on company owner and state-enterprise status at one point in time. This means that total steelmaking capacity per company can be computed as per ownership structure in 2019. This provides an accurate snapshot of the ownership structure of the industry in that year, but it does not yet allow to investigate accurately the effects of cross-border investment on firm-level capacity. References in the paper to firm-level capacity around cross-border investment instances, be it a mergers-and-acquisition deal or the announcement of a new steelmaking capacity project, assume that the ownership structure in place in 2019 was also in place at the time when the investment instance was realised (see section 5.4). For instance, if a steel company was state-owned in 2019 , it is assumed that it was also state owned at the time of the construction of a new steelmaking plant or at the time of an acquisition of a steel-related company. The same assumption applies to investors that were non-state-owned in 2019. Figure 1 shows the absolute and relative value of state-owned capacity at the jurisdiction level for OECD countries, China and other economies. 


\section{Figure 1. Installed steelmaking capacity by region and ownership, 2019}

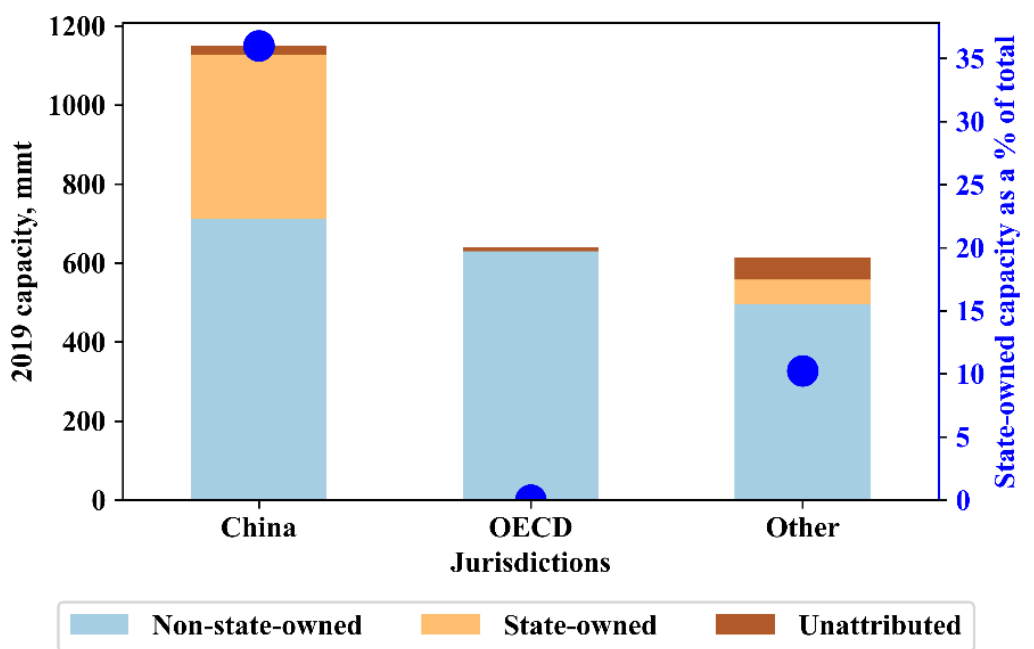

Note: OECD contains the organisation's members as of the end of 2019. Ownership was unattributed when no sufficient information could be found or for those jurisdictions (most notably the Islamic Republic of Iran, hereafter Iran) which were added to the OECD plant-level capacity data set after June 2020, the cut-off point for the preparation of the data for this report.

Source: OECD

\subsection{Types of cross-border investment}

Data are available on two types of cross-border investment, which are discussed in the remainder of the paper. On the one hand, an investor may decide to build a new steelmaking facility or expand an existing facility in a jurisdiction different from the domicile of the investor. Throughout the paper this kind of investment will be referred to as a greenfield project. The data set containing information on this type of investment is the projects data set, described in Annex A. On the other hand, cross-border investment may comprise a merger-and-acquisition deal involving a buyer and a target domiciled in two different jurisdictions. The data on cross-border deals comes from the Dealogic data set, described in Annex B.

The two data sets differ in five noteworthy ways: i) the geographical coverage is global for projects while for mergers and acquisitions the coverage exclude a handful of jurisdictions ${ }^{30}$ ii) data are available for 2014, 2017, 2018 and 2019 for greenfield projects and between 2000 and H1 2019 for mergers and acquisitions; iii) data in the acquisitions data set represent closed deals, while data in the projects data set are publicly stated intentions to build new steelmaking capacity; iv) projects contain information on steelmaking plants and investing companies, while the merger-and-acquisition data set contains information on investing companies and target companies; therefore v) projects are listed in million metric tonnes (mmt), while deals are quoted in USD million.

As investment may at times involve more than one investor (or more than one target), crossborder investment is defined here as investment in which at least one relationship between investor and target is cross-border. Cross-border investors are those which carry out a crossborder transaction. When cross-border investors have investment partners in the target jurisdiction, these latter are not considered cross-border investors. To insure that the sample of investment instances bears relation with steelmaking capacity, all instances included have at least one investor or one target matched in the OECD capacity data set. 


\subsection{General remarks about the analysis}

The aim of the analysis carried out in the paper is to highlight differences between stateowned and non-state-owned enterprises in cross-border investment along a series of outcomes that are relevant to the steel industry. At this stage, the analysis has been carried out on counts of investment. As a consequence, the results presented in the paper illustrate differences in the frequency of investment and may differ from results based on investment size.

As investment may at times involve more than one investor (or more than one target), crossborder investment is defined here as investment in which at least one relationship between investor and target is cross-border. Cross-border investors are those which carry out a crossborder transaction. When cross-border investors have investment partners in the target jurisdiction, these latter are not considered cross-border investors. To insure that the sample of investment instances bears relation with steelmaking capacity, all instances included have at least one investor or one target matched in the OECD capacity data set.

\subsection{General remarks about the analysis}

The aim of the analysis carried out in the paper is to highlight differences between stateowned and non-state-owned enterprises in cross-border investment along a series of outcomes that are relevant to the steel industry. At this stage, the analysis has been carried out on counts of investment. As a consequence, the results presented in the paper illustrate differences in the frequency of investment and may differ from results based on investment size.

Only a small number of counts of cross-border investment by state-owned enterprises was found in the data sets. For instance, Table 7 shows a total count of 30 state-owned crossborder investment split in two categories (state-owned and non-state-owned) and distributed across three outcomes. This means that even small changes in the data, could change the results showed. Also as a result of small numbers, the statistics reported are descriptive, rather than explanatory.

China is the jurisdiction of origin of many more state-owned cross-border investors than any other geography covered in this analysis, and indeed of all other geographies consider together (see Figure 4 and Figure 5). This means that conclusions on the characteristics of state-owned enterprises are coloured by the role of China and results should be read bearing in mind the role of China. 


\title{
4. Characteristics of cross-border investment and investors in the steel industry
}

\begin{abstract}
State-owned enterprises differ from non-state-owned enterprises at the very least in their justification. This may be derived from governments' attempts at managing market failures, or it may be an expression of societal or ideological preferences over the handling of economic sectors or activities (Cuervo Cazurra et al., 2014, pp. 3-4[6]). Additionally, the economic performance of state-owned enterprises has generally proven to be weaker than non-state-owned enterprises, particularly in sectors where competition is higher (IMF, 2020 , pp. 56-58[25]). These include the steel sector (Mattera and Silva, 2018, p. $4_{[2]}$ ). It can thus be expected that differences exist in general investment preferences and patterns between state-owned and other enterprises.

This section explores key differences between state-owned and non-state-owned investors in the steel industry and summarises some of the characteristics of cross-border investment and cross-border investors. Among other things, the section highlights the concentration of cross-border state-owned investors in China.
\end{abstract}

\subsection{General investment preferences}

\subsubsection{Domestic vs cross-border investment}

Between 2000 and 2019 there were 3388 merger and acquisition deals in the steel sector, as reported by Dealogic. In these deals, state-owned investors displayed a higher domestic bias than non-state investors. That is, $82.2 \%$ of total merger-and-acquisition deals by stateowned enterprises were directed domestically, compared to $64.0 \%$ of deals by non-stateowned enterprises. ${ }^{31}$ This tallies with broader expectations - not exclusive to the steel sector - concerning the domestic bias of state-owned enterprises (Lehmann and Tavares-

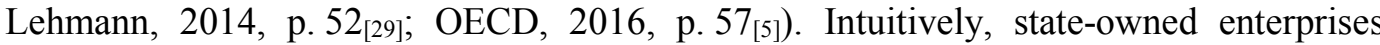
should have a greater focus on activity in their jurisdiction, as their mandate is most likely linked to advancing societal goals relevant to their home jurisdiction.

However, when looking at the greenfield projects - data for which is available for the years 2014, 2017-19 - the picture is reversed. For greenfield projects, state-owned enterprises display a lower domestic bias than other enterprises. As summarised in Table 1, domestic investment represented $62.5 \%$ of greenfield investment counts by state-owned enterprises and $75.7 \%$ by others. ${ }^{32}$ In sum, compared to other firms, state-owned enterprises have a lower propensity to invest abroad overall, but when they do invest abroad, they are more prone than other enterprises to invest in a greenfield project. As Chinese investors represent the majority of state-owned cross-border investors (see Figure 5), this is likely the result of the Chinese government policies to support the construction of steelmaking capacity abroad (see section 2.2).

Table 1. Domestic bias in greenfield investment projects by investor ownership

\begin{tabular}{l|r|r|r}
\hline & \multicolumn{3}{|c|}{ Investment by destination } \\
\hline $\begin{array}{l}\text { Investment by investor } \\
\text { ownership }\end{array}$ & Cross-border & Domestic & All \\
\hline Non-state-owned & 68 & 212 & 280 \\
\hline State-owned & 36 & 60 & 96 \\
\hline All & 104 & 272 & 376 \\
\hline
\end{tabular}

Note: $\chi^{2}(1, \mathrm{~N}=376)=5.596, \mathrm{p}=.018$

Source: OECD 
In terms of capacity, however, state-owned enterprises directed abroad a smaller share of total capacity expansion plans than non-state-owned enterprises. In the period 2014-19, state-owned enterprises planned capacity expansions for a total of $241 \mathrm{mmt}$, of which $29.9 \%$ in cross-border projects. Non-state-owned enterprises planned total capacity expansions of $396 \mathrm{mmt}$ which $37.1 \%$ were cross-border projects. The average size of a domestic project stood at $1.2 \mathrm{mmt}$ for non-state-owned enterprises and $2.9 \mathrm{mmt}$ for stateenterprises. The average size of a cross-border project stood at $2.3 \mathrm{mmt}$ for non-stateowned enterprises and $1.9 \mathrm{mmt}$ for state-owned enterprises.

The weaker domestic bias of state-owned enterprises in the projects data compared to the mergers-and-acquisition data may be explained by an evolution of preferences, but the evidence in the data analysed here is inconclusive. Looking only at the period 2014-19 (for which data are available for both merger-and-acquisition deals and greenfield projects), state-owned enterprises' bias for domestic investment appears to be lower than that of other enterprises also for merger-and-acquisition deals. However, contrary to differences in the greenfield data, which are sizeable and significant, differences in the merger-andacquisition data (limited to the years 2014-19) are both small and not statistically significant.

While the domestic bias of state-owned enterprises may be weakening, it is hard to identify a trend in the data. In part this is due to the different time coverage in the merger-andacquisition deals and in the projects data set, illustrated in Figure 2. It is also possible that the preference for domestic investment is different across investment types and it may be stronger for mergers and acquisitions than for greenfield projects. For instance, the acquisition of an asset by a state-owned foreign firm may be more contentious than the construction of a new asset. A longer time series of cross-border investment may improve our understanding of how cross-border investment preferences may be evolving.

\section{Figure 2. Cross-border investment in steel}

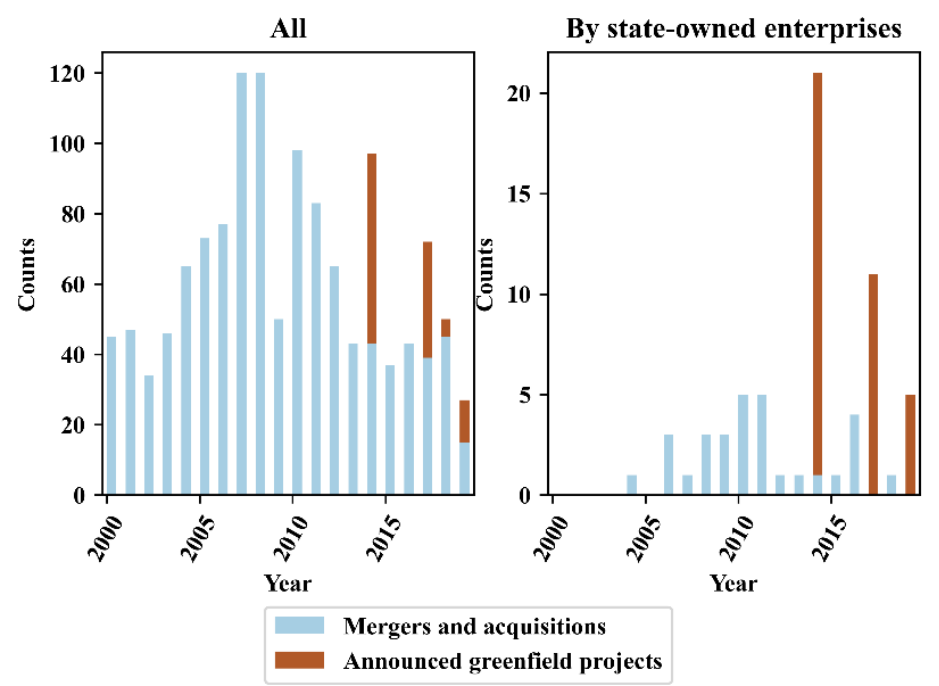

Note: For the year 2019, merger-and-acquisition data were available only for the first six months. The 2014 spike in announced greenfield projects is due to the timing of the projects database, first available in 2014. Source: Dealogic, OECD.

\subsubsection{Mergers and acquisitions vs commissioning of new capacity}

Overcapacity is a persistent problem in the steel industry. Preferences in the type of investment are relevant to gauge the potential of cross-border investment by state-owned 
enterprises to exacerbate the problem. In particular, mergers and acquisitions per se do not alter the stock of existing capacity. First, although mergers and acquisitions may be accompanied by capacity closures or expansions, they do not intrinsically result in the construction of new steelmaking capacity but only in the change of hands of some already existing capacity. ${ }^{33}$ Second, mergers and acquisitions may involve deals in different parts of the steel industry value chain, often involving upstream (mining) or downstream (for instance re-rolling) assets with no steelmaking facilities attached to them. As such, the contribution of mergers and acquisitions to excess capacity is likely to be smaller than that of greenfield investments.

Between 2000 and 2019 there were 4407 counts of completed investment in the steel sector, defined as the completion of a merger and acquisition deal, as reported by Dealogic or the commissioning of new steelmaking capacity, as reported in the OECD plant-level capacity database. These counts include domestic and cross-border investment. ${ }^{34}$ For 4 305 of these cases, the ownership status (state or non-state) was known. Of these counts of completed investment, 337 (equivalent to $7.6 \%$ ) were carried out by state-owned enterprises.

\subsubsection{Mergers and acquisitions vs commissioning of new capacity}

Overcapacity is a persistent problem in the steel industry. Preferences in the type of investment are relevant to gauge the potential of cross-border investment by state-owned enterprises to exacerbate the problem. In particular, mergers and acquisitions per se do not alter the stock of existing capacity. First, although mergers and acquisitions may be accompanied by capacity closures or expansions, they do not intrinsically result in the construction of new steelmaking capacity but only in the change of hands of some already existing capacity. ${ }^{35}$ Second, mergers and acquisitions may involve deals in different parts of the steel industry value chain, often involving upstream (mining) or downstream (for instance re-rolling) assets with no steelmaking facilities attached to them. As such, the contribution of mergers and acquisitions to excess capacity is likely to be smaller than that of greenfield investments.

Between 2000 and 2019 there were 4407 counts of completed investment in the steel sector, defined as the completion of a merger and acquisition deal, as reported by Dealogic or the commissioning of new steelmaking capacity, as reported in the OECD plant-level capacity database. These counts include domestic and cross-border investment. ${ }^{36}$ For 4 305 of these cases, the ownership status (state or non-state) was known. Of these counts of completed investment, 337 (equivalent to $7.6 \%$ ) were carried out by state-owned enterprises.

By counts, $49.9 \%$ of completed investment by state-owned enterprises were greenfield capacity expansions while for non-state-owned investors the propensity to build new capacity stood at a much lower $18.9 \%$, as illustrated in Table 2 , which also shows that the difference is statistically significant.

Data on the amount of steelmaking capacity transacted in individual merger-andacquisition deals is not available, but the commissioning of new capacity throughout the period totalled 1577 million metric tonnes $(\mathrm{mmt})$, calculated from a total of 1017 investment counts, of which $26.3 \%$ was by state-owned enterprises (165 investment counts or $16.2 \%$ of total counts).

The right panel of Figure 3 shows that state-owned enterprises' stronger preference for commissioning capacity is more evident in the earlier part of the series, particularly until 2015 and may be explained by the launch by the Chinese government of the Supply-Side Structural Reforms in December that year. As noted in Section 2. of this paper, the reforms 
set targets for capacity reduction, promoted consolidation in the steel industry, and tightened requirements for the construction of new steelmaking capacity.

\section{Figure 3. Instances of completed investment in the steel sector}

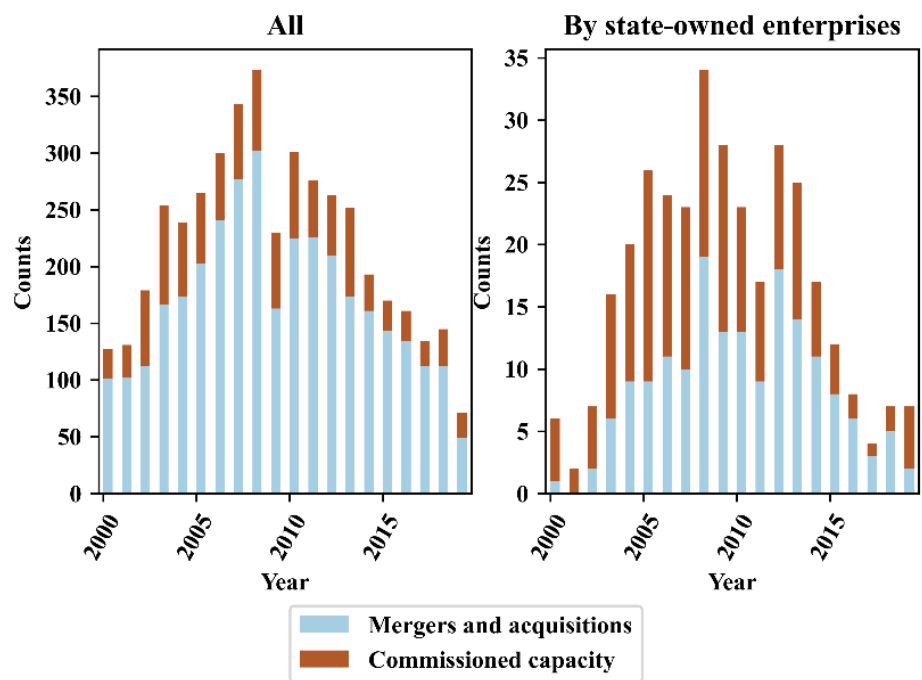

Note: For the year 2019, merger-and-acquisition data were available only for the first six months. Source: Dealogic, OECD.

Table 2. Frequency of investment by type 2000-19

\begin{tabular}{l|l|l|l}
\hline & \multicolumn{2}{|c}{ Investment by type } & \\
\hline Investment by ownership & Merger and acquisition & Commissioned capacity & Total \\
\hline Non-state-owned & 3219 & 749 & 3968 \\
\hline State & 169 & 168 & 337 \\
\hline Total & 3388 & 917 & 4305 \\
\hline
\end{tabular}

Note: $\chi^{2}(1, \mathrm{~N}=4305)=175.945, \mathrm{p}=.000$. For mergers and acquisitions, each target was counted as a separate instance. One deal with three targets was therefore counted three times. For commissioned capacity, capacity starts of different pieces of equipment at the same steelmaking plant were counted as separate investment instances if they occurred in different years. If they occurred in the same year, they were counted as one investment instance.

Source: Dealogic, OECD.

Looking at all counts of completed investment, including domestic and cross-border investment, the preference for greenfield investment displayed by state-owned enterprises is markedly stronger, which is not surprising. In industrial sectors, state-owned enterprises may be used as a tool to implement industrial policy, precisely aimed at developing an industry (Cuervo Cazurra et al., 2014, p. $\left.4_{[6]}\right)$. And governments may decide to develop a domestic industry even in sectors prone to overcapacity (Barwick, Kalouptsidi and Zahur, $2019_{[30]}$ ), such as shipbuilding or steel. When focusing on cross-border investment, however, the pursuit of industrial development, and therefore the preference of greenfield investment over mergers and acquisitions is less straightforward to understand.

While building new plants may be a means to build an industry, industrial policy is typically devoted to domestic industrial development. Yet, the stronger preference among stateowned enterprises for building new capacity over acquiring existing capacity holds true also in the cross-border investment data set. Restricting the comparison to the years 201419 for which data exist for both cross-border merger-and-acquisition deals and greenfield 
projects, ${ }^{37}$ the difference between state-owned enterprises and non-state-owned enterprises remains significant, as illustrated in Table 3.

Table 3. Type of cross-border investment by investor ownership 2014-19

\begin{tabular}{l|r|r|r}
\hline & \multicolumn{2}{|c|}{ Investment type } & All \\
\hline $\begin{array}{l}\text { Cross-border investor } \\
\text { ownership }\end{array}$ & Mergers and acquisitions & Greenfield & 283 \\
\hline Non-state-owned & 215 & 68 & 43 \\
\hline State-owned & 7 & 36 & 326 \\
\hline All & 222 & 104 & \\
\hline
\end{tabular}

Note: $\chi^{2}(1, \mathrm{~N}=326)=58.508, \mathrm{p}=0.000$.

Source: Dealogic, OECD.

In summary, compared to other enterprises, state-owned firms displayed a stronger preference for additional steelmaking capacity relative to acquiring existing assets as a form of investment. This appeared to be the case both overall, and - at least for the years 201419 , for which data is available - for cross-border investment. Additionally, in the years 2014-19, state-owned enterprises displayed a comparatively lower domestic bias than other enterprises in their choice of investment destination. Although by mmt the share of capacity planned across borders is lower for state-owned enterprises than for others, the outward investment orientation of state-owned enterprises indicates their potential as propagators of excess capacity.

\subsection{Cross-border investors}

In the merger-and-acquisition data set there were 1376 unique investors. Over the period 2000 to $2019,64.9 \%$ (893) of the total only took part in domestic merger-and-acquisition deals, $25.0 \%$ (344) only took part in cross-border deals and the remaining $10.1 \%$ (139) took part in both. Of the cross-border investors, 17 (3.5\%) were state-owned enterprises. Matches in the OECD steelmaking capacity database could be found for 238 investors in total and for 120 cross-border investors.

For the matched data, state-owned investors (in both domestic and cross-border mergerand-acquisition deals) typically had a larger operating steelmaking capacity than other investors. ${ }^{38}$ State-owned enterprises also engaged in fewer cross-border deals per firm than other enterprises (1.4 and 2.5 deals per firm respectively). And they were more likely than non-state-owned firms to be one of a group of buyers in a cross-border merger-andacquisition deal. State-owned enterprises had partners in in $19.5 \%$ of the cross-border merger-and-acquisition deals they entered, compared to $7.0 \%$ for non-state-owned enterprises.

\subsection{Cross-border investors}

In the merger-and-acquisition data set there were 1376 unique investors. Over the period 2000 to $2019,64.9 \%$ (893) of the total only took part in domestic merger-and-acquisition deals, $25.0 \%$ (344) only took part in cross-border deals and the remaining $10.1 \%$ (139) took part in both. Of the cross-border investors, 17 (3.5\%) were state-owned enterprises. Matches in the OECD steelmaking capacity database could be found for 238 investors in total and for 120 cross-border investors.

For the matched data, state-owned investors (in both domestic and cross-border mergerand-acquisition deals) typically had a larger operating steelmaking capacity than other 
investors. ${ }^{39}$ State-owned enterprises also engaged in fewer cross-border deals per firm than other enterprises ( 1.4 and 2.5 deals per firm respectively). And they were more likely than non-state-owned firms to be one of a group of buyers in a cross-border merger-andacquisition deal. State-owned enterprises had partners in in $19.5 \%$ of the cross-border merger-and-acquisition deals they entered, compared to $7.0 \%$ for non-state-owned enterprises.

With respect to the higher propensity of state-owned enterprises to enter deals in partnership with other buyers, the merger-and-acquisition data set offers some additional nuance, as it allows to identify state-owned enterprises that are funding bodies. Following further tagging (see section 3.1), two types of state-owned enterprises were identified. Of the 17 state-owned cross-border investors, 2 were not steelmakers. These were included as they entered a cross-border deal where a steelmaking firm originating from the same jurisdiction also acted as a cross-border buyer. For instance, of the cross-border stateowned investors identified in the right panel of Figure 4, the Korean and Japanese investors were not steelmakers, but buyers in multi-buyer cross-border deals in which steelmakers took part.

Figure 4 illustrates the geographical origin of cross-border investors, showing how, while most cross-border non-state-owned investors are from OECD countries, most state-owned cross-border investors, both of the steelmaking and financial type, originate in China.

\section{Figure 4. Count of cross-border investors in merger-and-acquisition deals by origin}

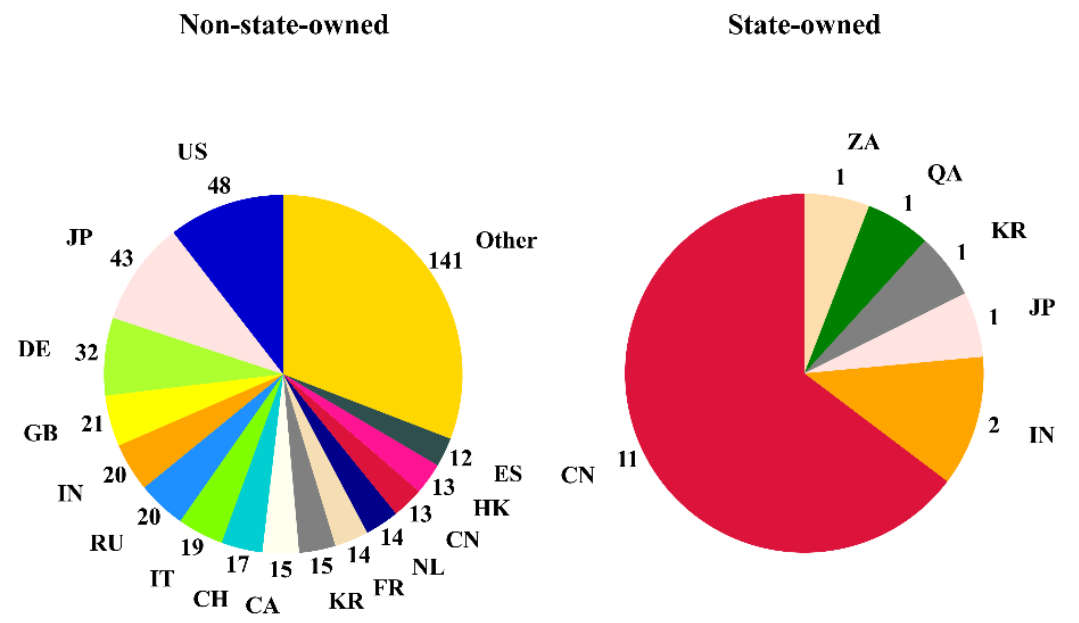

Source: Dealogic, OECD.

State-owned enterprises were found to be larger and have a greater propensity to enter foreign investment in partnership with other investors also with respect to data in the greenfield projects data set. This contains a total of 298 investors. Of these, 208 engaged only in domestic greenfield capacity projects, 58 only in cross-border projects and 14 in both. For 94 domestic investors and 33 cross-border investors a match was available in the OECD steel capacity database. Average firm capacity stood at $9.6 \mathrm{mmt}$ and $19.7 \mathrm{mmt}$ for domestic and cross-border investors respectively, ${ }^{40}$ a sizeable and significant difference, ${ }^{41}$ suggesting that companies investing abroad are larger than companies investing in the domestic markets. This difference remains sizeable and significant also if we consider non- 
state-owned enterprises, but differences between domestic and cross-border investors of the state-owned type are not significant.

As is the case for cross-border merger-and-acquisition deals, state-owned enterprises were more likely than other enterprises to enter cross-border greenfield projects with partners. State-owned enterprises entered joint ventures in $27.8 \%$ of their cross-border greenfield projects compared to $13.2 \%$ of non-state-owned enterprises. ${ }^{42}$

In the years between 2014 and 2019 for which data were available, there were 2.8 crossborder projects for each state-owned cross-border investor, compared to an average of 1.3 project per every non-state-owned cross-border investor, the inverse of the preferences noted for cross-border and acquisition deals. ${ }^{43}$

In the years between 2014 and 2019 for which data were available, there were 2.8 crossborder projects for each state-owned cross-border investor, compared to an average of 1.3 project per every non-state-owned cross-border investor, the inverse of the preferences noted for cross-border and acquisition deals. ${ }^{44}$

These characteristics - larger size, lower propensity to purchase existing assets and inclination to enter agreements with other firms - confirm the validity in the steel sector of some generally held expectations about state-owned enterprises. In particular, the preference for greenfield investment seems to be consistent with the larger need (Cuervo Cazurra et al., 2014, p. 935 $5_{[6]}$ ) and practice (Tham and Yeoh, 2020, p. $7_{[10]}$ ) to engage in investment activity aimed at increasing the legitimacy of a foreign state-owned investor in a target jurisdiction. Building a new plant and increasing employment is likely to be better perceived than acquiring assets that the host jurisdiction may consider strategic. Similarly, joining other firms in a cross-border deal may help ease concerns of foreign control of strategic assets (Cuervo Cazurra et al., 2014, p. 935 $5_{[6]}$; Tham and Yeoh, 2020, p. $7_{[10]}$ ).

Additionally in the steel sector, preference for greenfield capacity is coloured by Chinese policies of investing in steelmaking capacity across borders (see section 2.2), as China represents by far the largest source of cross-border investment by state-owned enterprises, at least for the years studied. As illustrated in the right panel of Figure 5, China accounts for 8 out of the 13 state-owned cross-border investors. Other jurisdictions originating stateowned investors were India, the Gulf Cooperation Council and Qatar. As a reminder of the characteristics of the projects data, Figure 5 lists investors which announced the intention of building steelmaking capacity across a border. Projects for which an explicit cancellation could be found in the press were excluded from the data set. All other projects were kept in the data set. China was also the jurisdiction originating most investors in the non-stateowned group, while other jurisdictions were located primarily in East and South Asia and in the Middle East. ${ }^{45}$ 
Figure 5. Count of cross-border investors in greenfield projects by origin

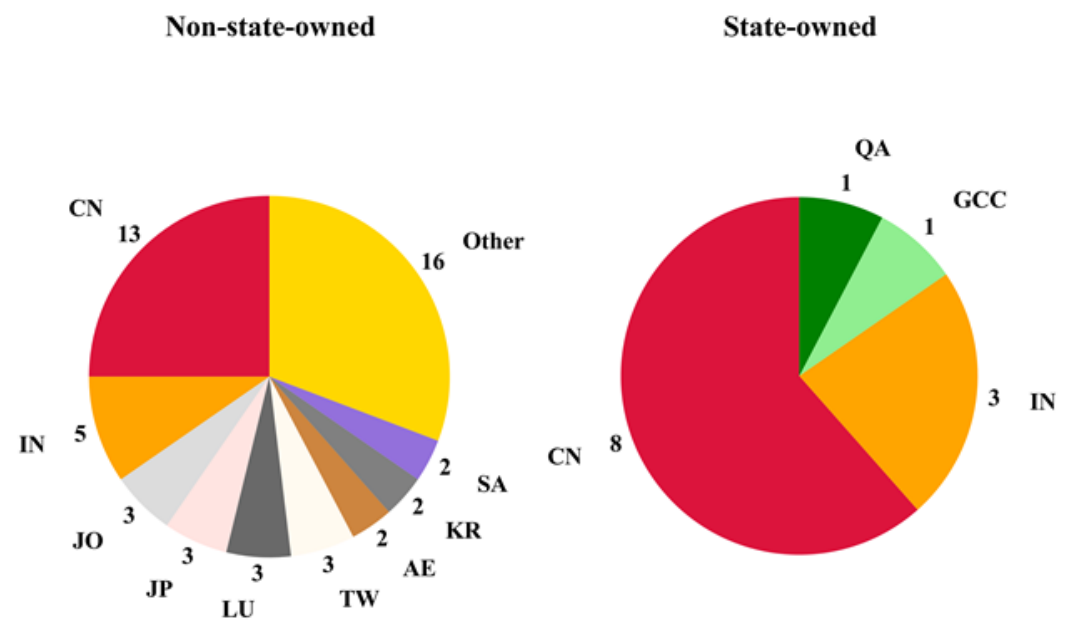

Note: Other contains jurisdictions with only one count of cross-border non-state-owned investor. The jurisdictions were: Iran, Great Britain, Germany, Argentina, Brazil, Mexico, Malaysia, Qatar, The Russian Federation, Sweden, Singapore, Thailand, Turkey and Kuwait. GCC is the Gulf Cooperation Council Source: OECD.

\subsection{Cross-border investment destination}

Cross-border investment in steel reached 96 jurisdictions between 2000 and 2019. Investment by state-owned enterprises targeted fewer destinations, amounting to 31 jurisdictions over the same period. For ease of visualisation, jurisdictions were grouped into regions in the figures Figure 6 and Figure 7. With the exception of cross-border greenfield projects by state-owned enterprises, the OECD area was the most popular destination for all types of investment.

Figure 6 and Figure 7 also shows other differences in regional preferences between nonstate-owned and state-owned enterprises. Looking at merger-and-acquisition deals by stateowned enterprises in the top-right panel, investment is sparse and no regional trend is neatly evident. Greenfield projects, on the other hand appear to have mostly directed to Southeast Asia, South Asia and Africa. While these are important destinations also of cross-border greenfield investment by non-state-owned enterprises, they dominated the choice of destinations for state-owned enterprises. Such regional concentration may reflect geographical proximity to state-owned investors, mostly based in China, and political saliency of the target jurisdictions, particularly as identified in the Chinese Belt and Road Initiative (see Box 2). 


\section{8}

| CROSS-BORDER INVESTMENT BY STATE-OWNED ENTERPRISES

Figure 6. Cross-border mergers and acquisitions by destination

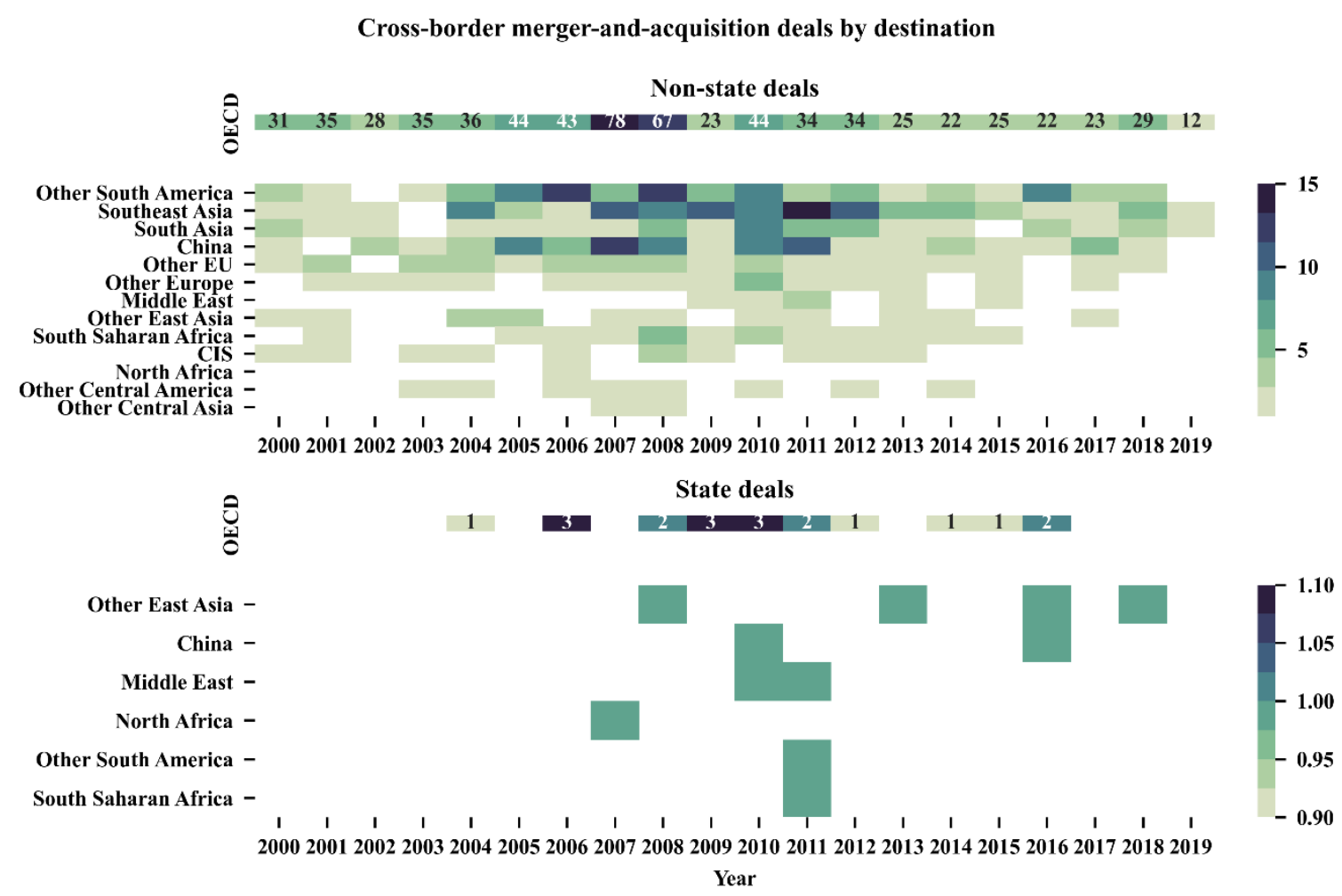

Note: The OECD is showed separately to allow for different scales. Regions are ranked by number of investment counts in the last 5 available observations the series: 2015 to 2019 in Dealogic and 2014, 2017 to 2019 for the projects data set. For the year 2019, merger-and-acquisition data were available only for the first six months. For regional groupings see Annex D.

Source: Dealogic, OECD. 
Figure 7. Cross-border greenfield projects by destination

Cross-border greenfield projects by destination

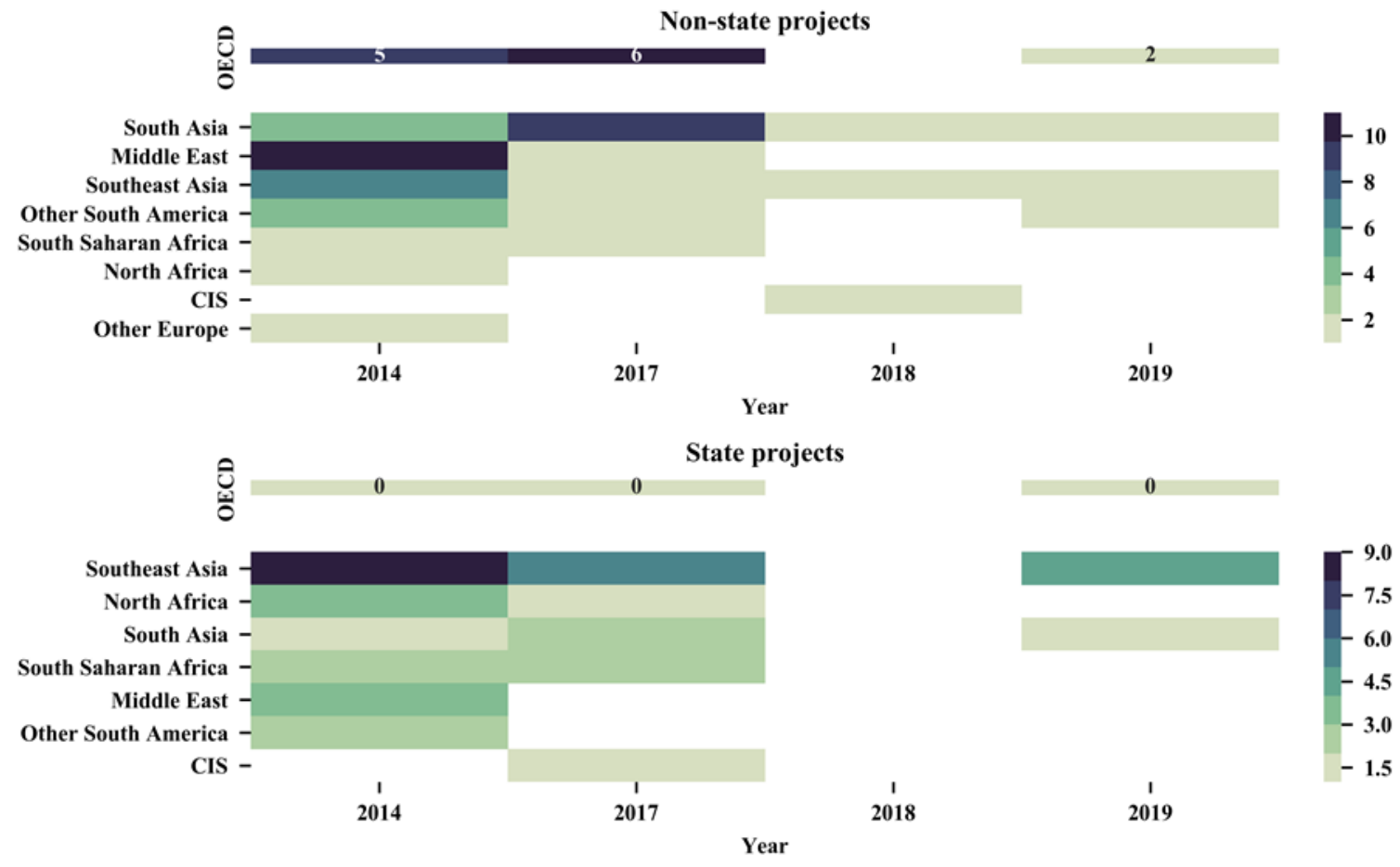

Note: The OECD is showed separately to allow for different scales. Regions are ranked by number of investment counts in the last 5 available observations the series: 2015 to 2019 in Dealogic and 2014, 2017 to 2019 for the projects data set. For the year 2019, merger-and-acquisition data were available only for the first six months. For regional groupings see Annex D.

Source: OECD.

In conclusion, data on the origin (Figure 4 and Figure 5) of state-owned cross-border investors show that state-owned enterprises engaged in cross-border investment are few and geographically concentrated - mostly originating from China. Meanwhile data on the destination of cross-border investment by state-owned enterprises (lower panels in Figure 6 and Figure 7) show that state-owned cross-border investment is directed mostly to Southeast Asia, North Africa and Southeast Asia as far as greenfield projects are concerned and to OECD countries for merger-and-acquisition deals. The prevalence of Southeast Asia as a destination for greenfield projects is likely to be linked to the Chinese policy initiatives detailed in section 2.2. The small number of observations for state projects and deals is a reminder that generalisations are not possible. 


\section{Cross-border investment and capacity changes}

The relationship between state-owned enterprises and excess capacity is complex. Stateowned enterprises could represent a tool to restructure the industry. However, previous research has shown that most of the capacity closures that took place in 2016 and 2017 were of private enterprises (Mattera and Silva, 2018, pp. 28, 30 $0_{[2]}$ ). Similarly, the newly completed China plant-level capacity data set shows that, even in China - where stateowned enterprises represented at least $33.8 \%$ of 2015 operating capacity - non-state-owned enterprises have contributed to most of the closures since 2015, both in terms of the number of plants closed and of tonnes of steelmaking capacity that has been shut down. Stateowned enterprises contributed less to capacity closures also relative to their share of capacity.

Previous research has proposed that, compared to other enterprises, state-owned enterprises may harm competitors as their proximity to the state confers them unfair advantages (Watanabe, 2020, pp. 26, 28 $8_{[3]}$; Kowalski and Perepechay, 2015 [11] $)$. As excess capacity remains a key concern for the steel industry, this section explores the relationship between investor's ownership and capacity outcomes in the aftermath of a cross-border investment instance at the jurisdiction level (both in the jurisdiction originating and receiving the investment) and at the level of the firm executing the investment - that is the buyer(s) in a cross-border merger-and-acquisition deal or the investor(s) in a cross-border greenfield project.

\subsection{Total capacity changes in the jurisdiction receiving the investment}

Based on the broad differences between state-owned and non-state owned enterprises, a concern surrounding state-owned enterprises is that their link to the state may distort competition (via the advantages they receive) with steel producers in the jurisdiction receiving the cross-border investment, or that state-owned enterprises may export overcapacity to the jurisdiction targeted by the investment or indeed both (Tham and Yeoh, 2020, p. $\left.7_{[10]}\right)$.

Data analysed here show that evidence of systematic differences between state and nonstate cross-border investment, in terms of their effects on capacity in the jurisdiction receiving the investment, is insufficient. The most common outcome in the aftermath of cross-border investment is no-change in the total capacity stock of the jurisdiction receiving the investment. Investment by state-owned enterprises is associated with capacity declines - see the right panel Figure 8 - more often than non-state-owned investment, which is most likely linked to capacity increases - left panel, Figure $8 .{ }^{46}$ 
Figure 8. Capacity changes in the target jurisdiction after a cross-border merger-and-acquisition deal

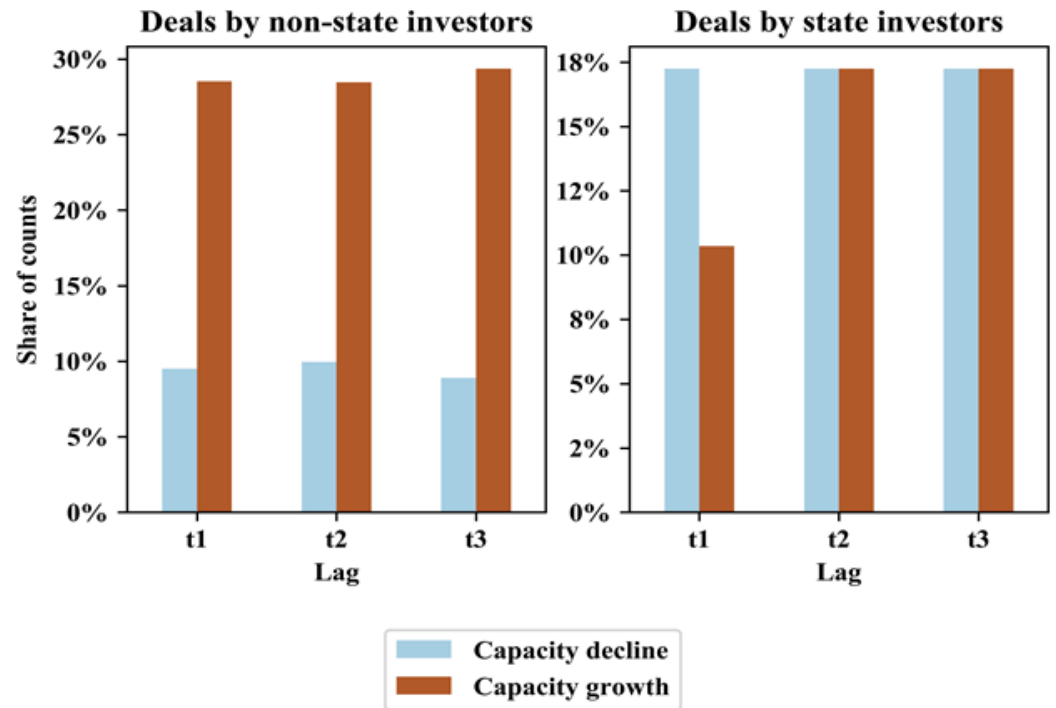

Note: Differences are not statistically significant Source: Dealogic, OECD.

Capacity outcomes appear to be a weaker differentiator between state-owned and other cross-border investment when it comes to capacity trends after greenfield projects are put in place. Information on a commissioning date is only available for 15 cross-border projects, five of which are by state-owned enterprises. Differences between cross-border investors by capacity outcome were not significant in any of the three years following an instance of cross-border investment. It is clear that the very small number of observations (15) and the relatively limited time-coverage $(2014,2017-19)$ means that no generalisation can be made with confidence.

Also when investment announcements are considered as the reference date instead of the year of commissioning of new capacity, ${ }^{47}$ the projects data set shows less consistent results than the cross-border and acquisition data, with a smaller sample and a weaker time anchor (project announcement for greenfield projects compared to completed deal for mergers and acquisitions).

Also when investment announcements are considered as the reference date instead of the year of commissioning of new capacity, ${ }^{48}$ the projects data set shows less consistent results than the cross-border and acquisition data, with a smaller sample and a weaker time anchor (project announcement for greenfield projects compared to completed deal for mergers and acquisitions).

In summary, the findings are inconclusive and at least for the period considered, capacity outcomes in the target jurisdiction are not a very good differentiator of state-owned and non-state-owned cross-border investment. In light of other findings in this paper that stateowned enterprises may be investing in jurisdictions with weak (or volatile) prospects for the steel sectors (see 6.1), and in light of findings from other research that state-owned cross-border investment may be pushing local steel producers out of business (Tham and Yeoh, 2020 $0_{[10]}$ ) or otherwise harming them (Watanabe, 2020, pp. 26, 28 $8_{[3]}$ ), more research is needed into the relation between cross-border investment by state-owned enterprises and capacity outcomes in the jurisdiction receiving that investment. 


\subsection{Capacity changes in the jurisdiction originating the cross-border investment}

A second capacity dimension which could distinguish investment by state-owned and nonstate-owned enterprises is the capacity trend in the jurisdiction of origin of the investor. Differences along this capacity dimension could point towards differences between stateowned and non-state-owned enterprises with regards to investment timing. Additionally, as most of cross-border investment by state-owned enterprises originate from China, capacity trends in China determine to a large extent the relationship between state-owned investment instances and capacity changes in the jurisdiction originating the investment, as detailed in section 5.3.

The right panel of Figure 9 shows that between $68.9 \%$ and $71.4 \%$ of cross-border deals by state-owned enterprises were followed by year-on-year capacity increases in the investor's jurisdiction in each of the three years following an investment. This represents a significantly higher share than what was experienced following deals by non-state-owned enterprises, where capacity increases in the jurisdiction of origin of cross-border investment occurred only for less than $30 \%$ of the deals. It has to be noted that the reverse is also true. Capacity declines were also more frequent in the aftermath of a cross-border investment by state-owned enterprises than by other enterprises, so that overall the capacity situation in the cross-border investor's jurisdiction was typically more stable for non-state-owned investors.

Figure 9. Capacity changes in the investor jurisdiction after a merger-and-acquisition deal

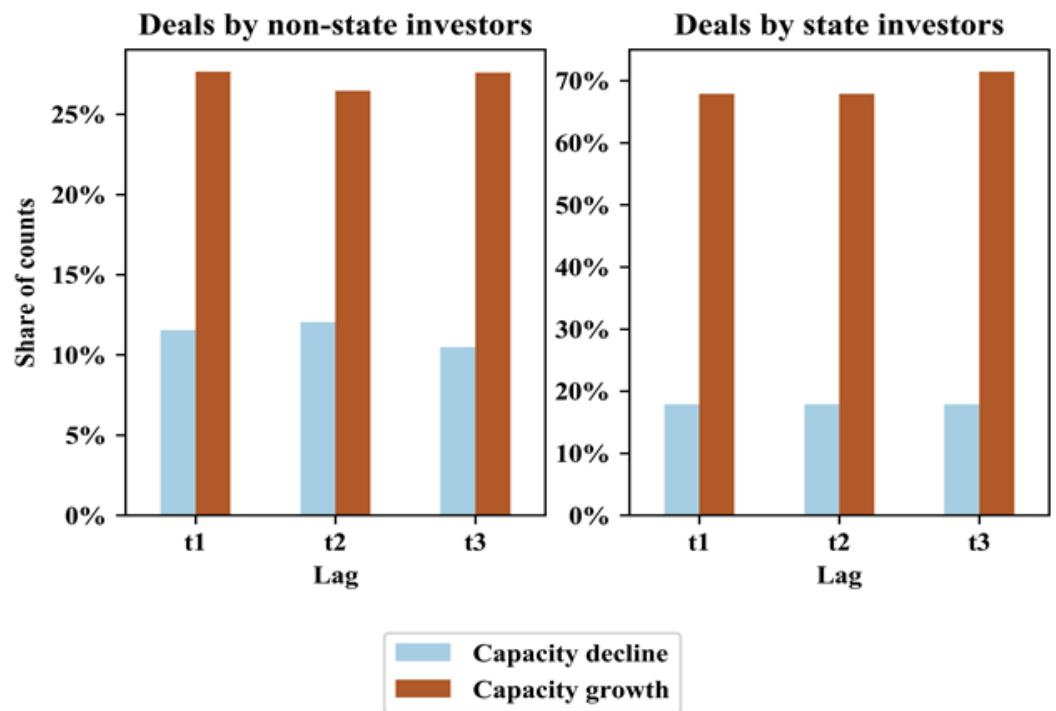

Note: Differences between state-owned and non-state-owned enterprises were significant in all periods. For example, in $\mathrm{t} 2: \chi^{2}(2, \mathrm{~N}=1196)=28.173, \mathrm{p}=.000$

Source: Dealogic, OECD

Cross-border investment of the greenfield-project type confirms the relationship highlighted by the cross-border mergers and acquisition data set. Considering cross-border investment of the greenfield type, only 18 observations had a commissioning date for the project. For those observations, the results were statistically significant for one period only. However, all periods pointed to the same pattern showing a stronger association between cross-border investment by state-owned enterprises and capacity declines in the jurisdiction of origin of the state-owned investor. 
Counting capacity changes from the year of announcement, the pattern is even more closely aligned with the relationship between ownership and capacity outcomes characteristic of cross-border merger-and-acquisition deals. State-owned enterprises have a stronger association with both capacity decline and growth in the investor's jurisdiction following a cross-border investment, as illustrated for the year-on-year growth on year 3 after the announcement of a cross-border investment in Table 4.

Table 4. Capacity changes in the investor jurisdiction, three years after a cross-border greenfield investment

\begin{tabular}{l|r|r|r|r}
\hline & Decline & Growth & No-change & \multicolumn{1}{c}{ All } \\
\hline Non-state-owned & 15 & 17 & 55 & 87 \\
\hline State-owned & 10 & 8 & 6 & 24 \\
\hline All & 25 & 25 & 61 & 111 \\
\hline
\end{tabular}

Note: $\chi^{2}(2, \mathrm{~N}=111)=11.571, \mathrm{p}=.003$. The distribution of ownership across the three capacity outcomes was statistically significant for each of the three years following the investment announcement.

Source: OECD

One way to read this finding is to say that cross-border investment by state-owned enterprises precedes periods of capacity changes in the jurisdiction originating the crossborder investment more often than cross-border investment by non-state-owned enterprises. However, as Chinese companies account for eight of the 13 state-owned enterprise engaged in cross-border greenfield project investment (see 2.2), the finding may simply point to the recent history of capacity changes in China. ${ }^{49}$

\subsection{The role of capacity change in China}

The role of capacity changes in China is critical to qualify the relationship between stateownership and capacity changes. Indeed, when controlling for the role of China, changes in capacity in the investor's jurisdiction cease to be a differentiator between cross-border investment by state-owned and non-state-owned enterprises and appear rather a differentiator between Chinese and non-Chinese cross-border investment, marking the more extensive capacity changes occurred in China compared to the rest of the world in the years 2000-19 analysed here.

For both cross-border merger-and-acquisition deals and cross-border greenfield projects, capacity changes in the investor jurisdiction after an investment instance are a strong differentiator between Chinese and non-Chinese investors as showed in Table 5 and Table 6. Meanwhile, when looking within China and in the rest of the world as a whole, capacity changes in the aftermath of a cross-border deal are not a consistently significant differentiator between state-owned and non-state-owned enterprises as cross-border investors. Some differences do exist between state-owned and non-state-owned crossborder greenfield-project investors ex-China. In particular, there seems to be an association between state-ownership and greater instability in the stock of capacity in the jurisdiction originating the cross-border investment. However, the very low count (5) of instances of state-owned cross-border investment and the narrow time window of the data $(2014,2017-$ 19) invite extreme caution in what can be said about capacity developments in the jurisdiction originating the investment as a differentiator between state-owned and nonstate-owned cross-border investors. 
Table 5. Capacity changes in the investor jurisdiction, one year after a cross-border merger and acquisition deal

\begin{tabular}{l|r|r|r|r}
\hline & Decline & Growth & No-change & All \\
\hline China & 10 & 28 & 0 & 38 \\
\hline World ex-China & 130 & 308 & 718 & 1133 \\
\hline All & 140 & 336 & 718 & 1194 \\
\hline
\end{tabular}

Note: $\chi^{2}(2, \mathrm{~N}=1194)=59.658, \mathrm{p}=.000$

Source: Dealogic, OECD

Table 6. Capacity changes in the investor jurisdiction, one year after a cross-border greenfield investment

\begin{tabular}{l|r|r|r|r}
\hline & Decline & Growth & No-change & All \\
\hline China & 24 & 13 & 0 & 37 \\
\hline World ex-China & 4 & 19 & 57 & 80 \\
\hline All & 28 & 32 & 57 & 117 \\
\hline
\end{tabular}

Note: $\chi^{2}(2, \mathrm{~N}=117)=65.447, \mathrm{p}=.000$

Source: OECD

\subsection{Capacity changes at the firm level}

Finally, state-owned and other cross-border investors may differ in capacity outcomes at the firm level. After all, any individual firm - including larger-than-average firms such as cross-border investors - has only a limited impact on the capacity trends of a jurisdiction. Capacity changes may occur at the firm level as firms may adjust capacity after a crossborder investment. For instance, firms may decide to relocate capacity from one jurisdiction to another. Alternatively, firms may advance investment in sprees, so that cross-border investment may be associated with other investment, resulting in capacity expansions at the firm level. ${ }^{50}$ It is not easy to check the association between firm-level capacity trends and cross-border investment in the available data sets, as these do not hold information about ownership changes over time. To begin investigating the relationship between stateownership of cross-border investors and firm-level capacity outcomes, an assumption is made here that the 2019 ownership structure of the steel industry was unchanged in the years $2000-19 .{ }^{51}$

In cross-border merger-and-acquisition deals, firm-level capacity changes do not appear to be a good differentiator between state-owned and non-state-owned cross-border investors. This is true for the entire sample of cross-border mergers and acquisitions, as well as for the Chinese sample only and the World-ex-China sample only.

Instead, firm-level capacity changes are a differentiator between state-owned and other enterprises when looking at cross-border greenfield investment. Compared to other firms, state-owned enterprises are more strongly associated with capacity declines at the corporate level (net of the newly-commissioned capacity) one, two and three years after commissioning and including all steelmaking assets owned by a firm in any jurisdiction in 2019. The number of observations available for commissioned capacity is however low 16 - and may once again reflect the overlap between state-owned enterprises and China. In order to increase the sample and to control for the China effect, the tests were repeated for capacity changes after cross-border investment announcements.

Also in that case, state-owned cross-border investors were more strongly associated with declines in capacity after a project announcement. ${ }^{52}$ The association holds true also when 
looking only at capacity changes at the corporate level within China where state-owned enterprises appear more closely linked to capacity declines after a cross-border investment than other enterprises. Though much weaker (and statistically significant only in the first year after the announcement), the difference appears also in the world ex-China. There, however, the count of state-owned enterprises is very low (five unique state-enterprise-year observations for four unique state-owned cross-border investors). The finding suggests that, among Chinese cross-border investors, state-owned firms have been more effective vehicles than other enterprises for the implementation of the capacity consolidation and export plans of the Chinese government (see section 2.2), closing capacity in China and planning to open capacity elsewhere.

Table 7. Chinese cross-border investor capacity changes, two years after project announcement

\begin{tabular}{l|r|r|r|r}
\hline & Decline & Growth & No-change & All \\
\hline Non-state-owned & 0 & 2 & 9 & 11 \\
\hline State-owned & 9 & 1 & 9 & 19 \\
\hline All & 9 & 3 & 18 & 30 \\
\hline
\end{tabular}

Note: $\chi^{2}(2, \mathrm{~N}=30)=7.751, \mathrm{p}=.021$

Source: OECD

Two points should accompany these findings. First, the finding highlights an interesting difference between two types of cross-border investment: acquisitions (where stateownership is not correlated with capacity changes at the corporate level) and greenfield projects (where state ownership and capacity changes are correlated). The difference would require further investigation, starting from the nature of the merger-and-acquisition deals. It is possible that many deals do not involve the acquisition of steelmaking capacity (see 3.4 and Figure 12). The completion of such deals would not trigger any rethinking of the steelmaking capacity stock at the firm level. Second, the findings apply to the time window captured by the greenfield projects data set. Most of the 2014 and 2017 cross-border investments by Chinese enterprises were carried out by state-owned enterprises, while nonstate-owned enterprises gained relative importance in the projects announced in 2018 and 2019 (see Figure 6 and Figure 7). On the one hand, this means that there might not have been enough time for non-state-owned enterprises to complete closures in the aftermath of a cross-border project announcement. ${ }^{53}$ Also the years immediately following 2014 were years of overall capacity decline in China adding further weight to the caution already suggested in the previous sections of the report. 


\section{Drivers of cross-border investment}

Assuming that commercial motives and constraints underpin cross-border investment by non-state-owned enterprises, differences with state-owned enterprises may suggest a departure of state-owned enterprises from market motives or market constraints. Three areas of motivation are considered here: steel-demand growth in the target jurisdiction; growth in trade remedies targeted at the jurisdiction of origin of the investment and the securing of strategic resources.

\subsection{Demand growth in the target jurisdiction}

The extent to which investors seek demand growth in the target jurisdiction may differ between state-owned and other enterprises. One of the generally recognised drivers for cross-border investment is the pursuit of new markets, and the size of the target market has been found to be an important consideration that helps explain the localisation of cross-

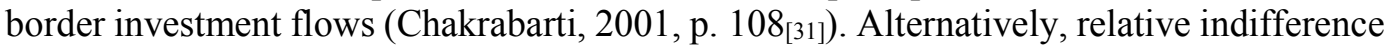
to growth in the target market could point to a cross-border investor being: i) bound by weaker market constraints (such as less pressure to maximise profit); ii) in pursuit of nonmarket objectives - such as strategic resource control or geopolitical influence (OECD, 2016, pp. 60-64 ${ }_{[5]}$; Bass and Chakrabarty, 2014 $\left.[7]\right)$.

In the steel industry, market size and growth prospects assume added relevance for their relation to excess capacity. Concerns voiced in the steel industry have focused on the inability of demand growth in economies targeted by foreign investment to absorb added production locally or regionally (Tham and Yeoh, 2020[10]).

Data analysed here show no significant difference in the size of the markets targeted by state-owned and non-state-owned cross-border investors. However, there is a difference between state-owned and other cross-border investors with respect to demand growth in the target jurisdiction. State-owned enterprises typically invest in markets with a recent history of higher steel demand growth $(6.3 \%)$ than non-state-owned investors $(1.7 \%){ }^{54}$

These findings are somewhat unexpected. They could suggest that state-owned enterprises target higher-growth regions in pursuit of a higher return for their investment. However, as customary for this relatively small data set, the findings need to be qualified. First, as seen in section 4.2, most state-owned cross-border investors originate in China. It is therefore understandable that most investment instances target economies in the proximity of China in East and Southeast Asia, as illustrated in Figure 10, right panel. 
Figure 10. Destination of cross-border investment by investor ownership

Non-state-owned

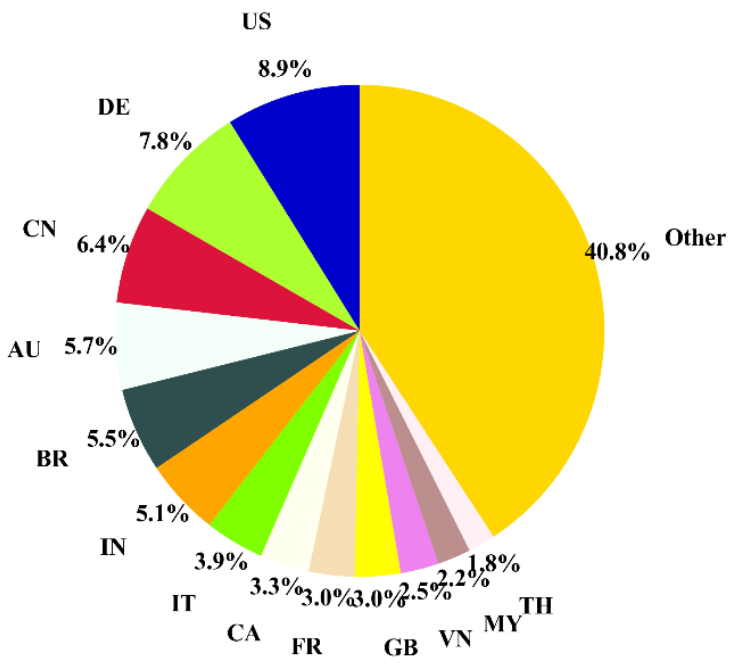

State-owned

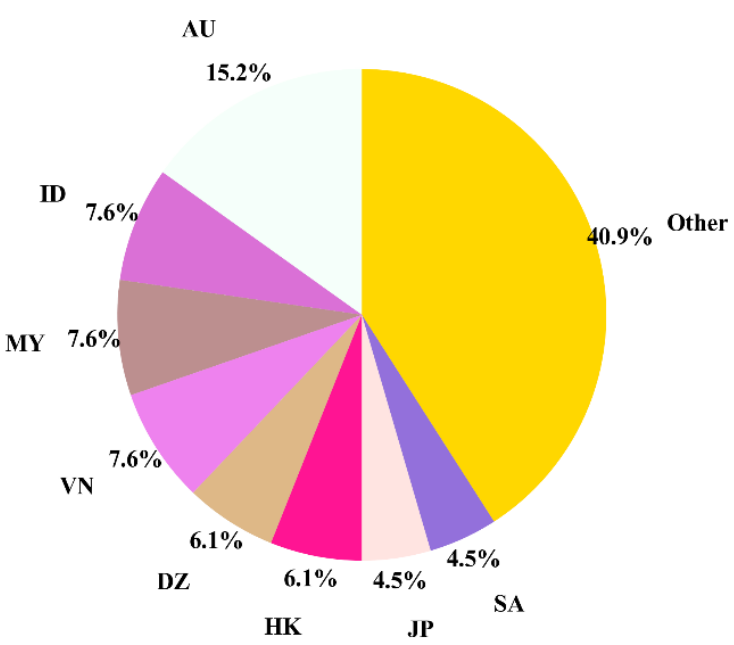

Source: Dealogic, OECD

Proximity and close cultural ties (as well as Chinese policies of foreign investment) are widely believed to influence the choice of destination for outward investment (Feng, Lin and Sim, 2019, p. 271 [32] $)$. As China is the jurisdiction of origin of most cross-border investment by state-owned enterprises, higher growth rates in the jurisdictions targeted by state-owned enterprises could simply reflect higher growth rates in the jurisdictions targeted by Chinese cross-border investors, or the higher growth rates in the geographies of Southeast Asia that happen to be geographically and culturally close to China. However, when we exclude China from the sample, steel demand growth before a cross-border investment remains significantly higher in destinations targeted by state-owned enterprises compared to growth in destination targeted by non-state-owned enterprises. ${ }^{55}$

While it is possible that state-owned enterprises may be seeking higher returns from their investment than other enterprises, it is also possible that their tolerance for risk is higher. Indeed, higher risk tolerance may be a by-product of lower market constraints and implicit government backing (Cuervo Cazurra et al., 2014, p. 12 [6]). Case-study research on crossborder investment by Chinese steel firms has suggested the hypothesis that state-owned enterprises are more risk-tolerating than other enterprises and target investment destinations perceived as more risky (Ren and Jack, 2015, p. $341_{[8]}$ ).

Indeed when checking the level of demand in the target jurisdiction another difference emerged. While steel-demand growth ahead of a deal is stronger for the deals by stateowned enterprise, the picture changes after a deal. Following deals involving state-owned enterprises, no significant demand growth was recorded in their target jurisdiction, while the median steel demand grew by $5.5 \%$ after a cross-border deal by other enterprises. This finding may indeed suggest that the jurisdictions targeted by state-owned cross-border investors may be characterised by more volatile growth and as such be a riskier investment. 
The finding also lends heft to the concern voiced by steel associations that demand growth in investment destinations targeted by state-owned cross-border investors may be insufficient to absorb additional production regionally. This calls for further investigation over the differences between state-owned and other enterprises in the choice of targets for their cross-border investment.

\subsection{Circumvention of trade remedies}

Also in the context of global steel overcapacity, policymakers are concerned with trade as a potential vehicle to propagate the effects of excess capacity across borders (Mattera, 2019 , p. $3_{[33]}$ ), and with cross-border investment as a means to extend unfair trading practices across borders. In order to counter exports sold at unfairly low prices, or subsidised by foreign governments, economies adopt anti-dumping and countervailing measures to remedy the injury caused by unfair trade imports. As trade remedy measures make it more difficult for the exporting companies to sell their products at the previous quantities (in the markets of economies where the measures are being imposed), it is reasonable to hypothesise that firms targeted by trade measures may try to bypass them by investing across borders (Brainard, 1997, p. 539 $[34]) .{ }^{56}$ Among others, differences between state and non-state-owned enterprises with respect to higher export costs could be of two types. First, due to their potential to receive greater support from the state, state-owned enterprises may be affected by trade remedies more often than non-state-owned enterprises. Second, after the imposition of a trade remedy, state-owned enterprises may face fewer constraints to engage in cross-border investment than non-state-owned enterprises as a way to avoid the fallout of higher export costs.

The cross-border investment data in this paper indeed suggest a correlation between crossborder investment by state-owned enterprises and the imposition of trade remedies in the year(s) before an investment instance. The difference is consistently significant for the merger-and-acquisition data, illustrated in Table 8, while significance is rather patchy for the data set on greenfield projects, illustrated in Table 9.

Table 8. Cross-border merger-and-acquisition deals and trade remedies

\begin{tabular}{l|r|r|r}
\hline & \multicolumn{3}{|c|}{$\begin{array}{c}\text { Change in number of remedies one year before a cross- } \\
\text { border investment instance }\end{array}$} \\
\hline Investor ownership & Growth & No growth & All \\
\hline Non-state-owned & 570 & 648 & 1218 \\
\hline State-owned & 23 & 5 & 28 \\
\hline All & 593 & 653 & 1246 \\
\hline
\end{tabular}

Note: $\chi^{2}(1, \mathrm{~N}=1246)=12.329, \mathrm{p}=.000$

Source: Dealogic, OECD

\section{Table 9. Cross-border greenfield projects and trade remedies}

\begin{tabular}{l|r|r|r}
\hline & \multicolumn{3}{|c|}{$\begin{array}{c}\text { Change in number of remedies two years before a } \\
\text { cross-border investment instance }\end{array}$} \\
\hline Investor ownership & Growth & No growth & All \\
\hline Non-state-owned & 56 & 32 & 88 \\
\hline State-owned & 22 & 3 & 25 \\
\hline All & 78 & 35 & 113 \\
\hline
\end{tabular}

Note: $\chi^{2}(1, \mathrm{~N}=113)=4.326, \mathrm{p}=.038$

Source: OECD 
However, once controlled for the Chinese role in state-owned cross-border investment, the correlation between ownership and trade remedies disappears and it is absent both within China and in the rest of the world. In sum, the correlation is between China as a jurisdiction of origin and trade remedies rather than between state-ownership and trade remedies. In particular, the correlation may be due to the fact that Chinese steel companies have been the object of new trade remedies every year since $1999 .{ }^{57}$

\subsection{Securing raw materials}

Concerns over the relationship between state-ownership and the security of raw materials supply (and other strategic resources more broadly) have traditionally focused on the role of the state as a target. Typically, states acting as shareholders decided whether or not to sell an asset considered strategic to a foreign firm. Less attention was paid to the motivations of a state as a cross-border buyer. With the opening of the Chinese mixed economy, the state as a cross-border buyer rose to greater prominence (Gordon and Milhaupt, 2019, p. 198 [35]; Oecd, 2008, pp. 3, 119 ${ }_{[36]}$ ). In the case of China, the twin aims of securing raw materials and strengthening relations with international partners, particularly in Southeast Asia and Africa have been a long-standing government consideration in authorising and encouraging outward investment (Deng, 2004, pp. 11, $\left.14_{[9]}\right)$. More broadly, long-term resource security has been found to be associated with cross-border investment by state-owned enterprises (Bass and Chakrabarty, 2014, p. 26 $6_{[7]}$ ). For instance, in the oil sector, Bass and Chakrabarty found that state-owned enterprises tend to invest in exploration projects while other enterprises prefer investing in exploitation deals which generate more immediate returns.

In the steel industry, resource seeking takes the form of acquisition of steelmaking rawmaterials assets, particularly mined raw materials such as iron ore and coking coal. To check whether differences exist between state-owned and other firms in pursuing access to raw materials, mergers and acquisition data were tagged to specify how deals spanned along the steel industry value chain (see section 3.1). The resulting additional dimension of the merger-and-acquisition data set is shown in Figure 11. The figure shows that a large percentage of investment instances, amounting to $58.7 \%$ for the whole data set and to $57.4 \%$ to the cross-border data set, could not be unambiguously assigned to upstream, steelmaking or downstream by the automated tagging. Additionally, the figure shows that for the deals that could be assigned to a category, upstream deals represented a greater share of cross-border deals, compared to all deals. 
Figure 11. Merger-and-acquisition investment counts by location on the value chain

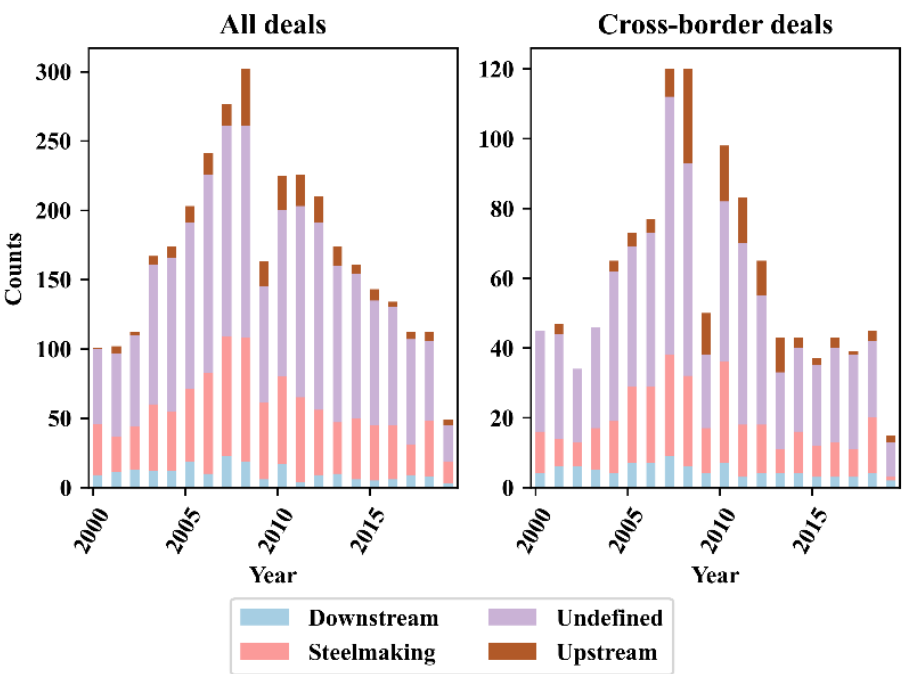

Note: For the year 2019, merger-and-acquisition data were available only for the first six months. Source: Dealogic, OECD

The tagged data (Figure 12) show that the overwhelming majority of cross-border deals involving state-owned enterprises is aimed at securing (across borders) influence over (or control of) resources required for the production of steel. These limited data suggest a difference in focus between state-owned and other cross-border investors, with other enterprises pursuing a wider variety of investment while state-owned investors focus more narrowly on securing the supply of steelmaking raw materials.

The number of cross-border investments by state-owned enterprises that could be tagged is however very small, seldom more than one a year and none in many years. Within these few investment counts, state-owned enterprises invested in downstream and steelmaking operations on two and one occasions respectively, generally preferring investment in upstream. Deals were directed to acquiring steelmaking operations only in one instance. In 2006, South African state-owned company Scaw Metals acquired Canadian Steelmaker Alta Steel from Severstal. The eight remaining deals were aimed at acquiring influence (defined as stakes of between $10 \%$ and $50 \%$ ) or ownership (defined as stakes of $50 \%$ or more) in iron ore or coal mining and prospecting companies with operations or projects in Australia, Mauritania, and Mozambique. 
Figure 12. Upstream and downstream counts of cross-border merger-and-acquisition investment

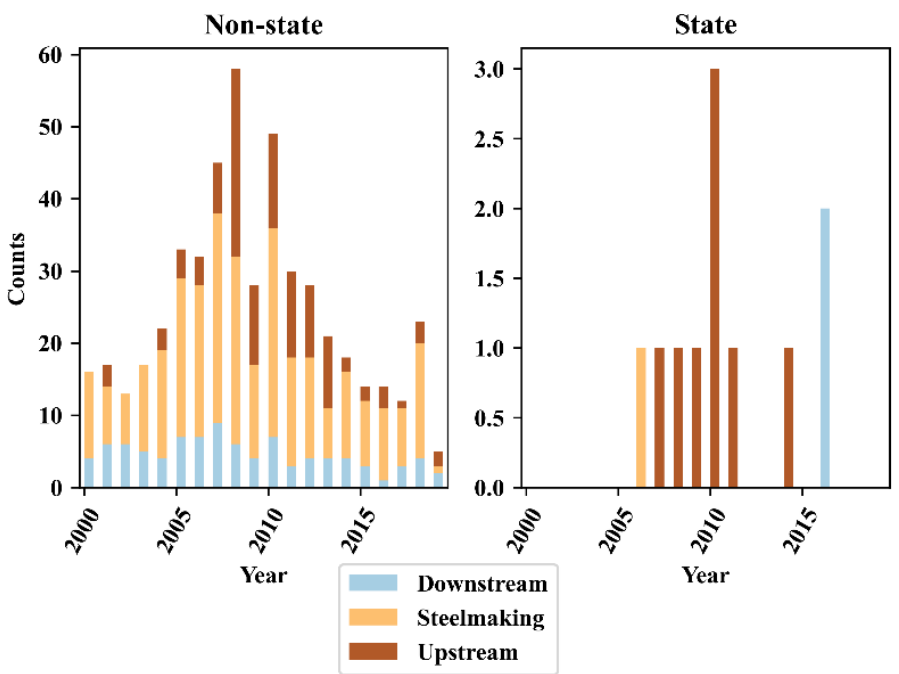

Note: Undefined or ambiguous tags are excluded from the visualisation. For the year 2019, merger-andacquisition data were available only for the first six months.

Source: Dealogic, OECD

More sophisticated tagging could increase the number of tagged deals for both state-owned and non-state-owned cross-border investors. As the number of deals for state-owned enterprises is very low, any increase could change the look of Figure 12 significantly, especially right panel. Therefore the conclusion that state-owned enterprises lean more than non-state-owned enterprises towards investment in companies in the upstream of steelmaking would appear to need further confirmation. 


\section{Conclusions}

Cross-border investment by state-owned enterprises in the steel sector is sizeable, particularly for the type of investment described in this paper as greenfield projects, which entails the investor's stated intention to build new capacity across borders (see section 4.1). As the steel sector continues to contend with excess capacity, policymakers express concerns that investment decisions may be taken by state-owned enterprises outside of the moderating effect of market constraints. In addition to its effect on overcapacity, crossborder investment by state-owned enterprises may extend market distortions across borders.

On the issue of excess capacity, data analysed in this paper indicated that in the aftermath of a cross-border investment, state-owned enterprises, particularly in China, were more strongly associated than others with capacity closures at the firm level (5.4). This suggests that state-owned enterprises were more disciplined in limiting capacity growth. Also, as China is the jurisdiction of origin of most state-owned cross-border investors (4.2), this also indicates that among cross-border investors, state-owned enterprises were more compliant than the others with the government requirements to reduce capacity in the aftermath of the Supply-Side Structural Reforms of 2015(4.1; 2.2). ${ }^{58}$ However, such association between state ownership and capacity decline has to be balanced with two other considerations.

First, while state-owned enterprises are generally less likely to invest abroad compared to others, when they do invest across borders, they are more inclined to invest in greenfield projects (see 4.1). State-owned enterprises extend their preference for additional capacity over acquisition also in their cross-border investment ventures. While there may be sound political reasons for state-owned enterprises to prefer greenfield investment (for instance to avoid the potential friction associated with a foreign takeover of assets that may be deemed strategic, (Cuervo Cazurra et al., 2014 $\left.4_{[6]}\right)$ ), greenfield projects may lead to capacity increases.

Second, the choice of destinations may make such capacity increases more likely to turn into excess capacity. From the analysis of capacity data, it emerges that state-owned enterprises tended to invest in jurisdictions characterised by greater demand volatility compared to the jurisdictions targeted by non-state-owned enterprises. This means that demand growth in those jurisdictions is unlikely to absorb the additional steel production, at least not reliably, which could in turn lead to excess capacity (Yeoh, 2020[37]) and transform target jurisdictions in steel-export outposts.

Regarding concerns over the levelness of the playing field, evidence of capacity closures in the jurisdictions targeted by state-owned enterprises is insufficient in the data analysed here. More broadly, further research is needed to corroborate this paper's findings since they are based on a very small number of cross-border investment counts, mostly originating in one jurisdiction (China).

Finally, state-owned and other enterprises differ with respect to the importance of seeking raw material resources as a driver for cross-border investment. Bearing in mind that the tagging of deals is still at a rudimentary stage, data suggest that resource seeking represent a more important driver for state-owned compared to non-state-owned cross-border investors. While many explanations could underpin this difference, one plausible hypothesis is that state-owned enterprises act as cross-border arms of government policies to secure long-term access to raw materials, particularly considering the relevance that ensuring a secure supply of raw materials had in long-held foreign investment priorities of the Chinese government (Deng, 2004 $\left.{ }_{[9]}\right)$. 


\section{Endnotes}

1 The OECD Business Survey on State Influence on Competition in International Markets was conducted to collect information on specific advantages granted to state-owned enterprises that result in most crossborder distortions and to compare them with advantages granted to private enterprises. The survey was sent to representatives of enterprises operating in the sectors characterised by traditionally close relations between the state and business (e.g. manufacture of steel, mining of steelmaking raw materials, air transport services, telecommunications services and energy). According to the obtained results, most respondents came from the steel sector (20\%) (for more details see (Kowalski and Perepechay, 2015[11])). Steel Committee's 2021-22 Programme of Work and Budget proposal (DSTI/SC(2020)8) suggests to conduct a new business survey with a specific focus on the steel industry, which will allow to collect new evidence on the impacts of operations of state-owned enterprises in the steel sector. This work will be conducted in close cooperation with steel industry associations.

${ }^{2}$ See GFSEC Tokyo Ministerial Meeting Chair's Report, 26 October 2020, available at: www.steelforum.org

${ }^{3}$ See Figure 4 and Figure 5.

${ }^{4}$ See GFSEC Tokyo Ministerial Meeting Chair's Report, 26 October 2020, available at: www.steelforum.org

${ }^{5}$ See Figure 4 and Figure 5.

${ }^{6}$ See 13th Five-Year Plan (2016-2020), Part XI, Chapter 49, Section 2

${ }^{7}$ See presentation by the Secretary General of the South East Asia Iron and Steel Institute Yeoh Wee Jin "The ASEAN Steel Industry Situation", 17 March 2020, Global Forum on Steel Excess Capacity http://www.steelforum.org/stakeholders/gfsec-march-2020-seaisi.pdf.

${ }^{8}$ Idem

${ }^{9}$ An additional topic identified by the Committee concerns the differences in economic performances between state-owned and non-state-owned cross-border investors. This requires the identification of a company's economic performance over time and across jurisdictions, a topic not treated in the current PWB.

10 These are: the OECD plant-level-capacity data set; the OECD projects data set; Dealogic's mergers-andacquisitions data set; Orbis financial and ownership data set. A fifth may be used at a later stage to build a history of steelmaking. Descriptions of the first three are found in the Annexes.

${ }^{11}$ See for instance (OECD, 2020 [28]; IMF, 2020, p. 47[25]).

12 Tagging state-controlled enterprises, using for example the definition provided in the OECD Guidelines on Corporate Governance of State-Owned Enterprises (OECD, 2015, pp. 14-16 [23]) is only possible with a very-small-n case study. Case studies are appropriate research tools for describing causality understood as a transmission mechanism though not appropriate to generalise results or quantify effects (Gerring, 2007, pp. 44-45[39]). For a brief summary of the issues around definition and operationalisation of state-owned enterprises seeBox 3 .

${ }^{13}$ Data on equity ownership does not systematically contain information on voting rights.

${ }^{14}$ Orbis also reports direct ownership at other thresholds, but in a more incomplete manner, preventing the automated construction of a full ownership tree.

${ }^{15}$ Automation was only possible in the plant-level-capacity data set, where companies had previously been tagged with Orbis identifiers.

${ }^{16}$ Non-steel state-owned enterprises are included in both the projects and the mergers-and-acquisitions data sets. The coding of these companies was achieved manually in the projects data set. In the mergersand-acquisitions data set, non-steel companies were included by adding the Dealogic definition of state enterprise to ours. This added a few non-steelmaking companies to our list of state cross-border investors. A caveat about this tolerance of Dealogic definition is that is narrower than the $50 \%$ threshold we have applied across data sets. It is therefore possible that the list of non-steelmaking state-owned enterprises (investing cross-border in the steel sector) may be longer. 
${ }^{17}$ For a more detailed description of these data sets see Annex A and Annex C respectively. Reasons for the low level of automation are manifold. Particularly for Chinese companies, precision - and the use of Chinese-characters names - is critical in determining the name of a company, and its status. Additional considerations apply to the projects data set. First, when the tagging was carried out, the geographical coverage of projects was broader than the plant-level-capacity data set (where the automation is possible). Second, projects are speculative so companies that are not already steelmakers may plan to engage in steelmaking. These companies may yet be included in the plant-level-capacity data set.

${ }^{18}$ However, all Iranian companies involved in the projects and merger-and-acquisition data sets have been tagged. Among the steel-producing economies still to be included are certain small South Asian steelproducing economies for instance Pakistan and Bangladesh.

${ }^{19}$ No systematic collection of data on greenfield investment in mining of steelmaking raw-materials or finishing of semi-finished and other intermediate steel products is available to the Secretariat.

${ }^{20}$ For instance when the same target was tagged as both upstream and downstream or as both a steelmaker and one of either upstream or downstream.

${ }^{21}$ These are companies listed as Government (not listed) in the PublicStatus field of the Dealogic data set. This list is a broader than the state-owned enterprises tagged in the plant-level capacity data set. The Dealogic Government (not listed) group may include two types of companies not identified in the plantlevel data set. Firstly, it includes companies that are state-owned and involved in steel-related deals (in which one of either buyer or target is matched to the steelmaking capacity data set), but are not steelmakers and therefore have no match in the plant-level capacity data set. Secondly, Dealogic definition can also identify state-owned steelmaking companies that have changed name or ownership before 2019 and could not therefore be matched in the plant-level capacity data set. For this reason, the Dealogic-based tagging was included in the definition of state-owned cross-border investors when state-owned enterprises identified by Dealogic supported buyers matched in the plant-level capacity data set.

${ }^{22}$ A more sophisticated (or resource intensive) tagging methodology would be necessary to investigate more systematically the different types of deals along the steel value chain as well as different kinds of cross-border investors.

${ }^{23}$ However, all Iranian companies involved in the projects and merger-and-acquisition data sets have been tagged. Among the steel-producing economies still to be included are certain small South Asian steelproducing economies for instance Pakistan and Bangladesh.

${ }^{24}$ No systematic collection of data on greenfield investment in mining of steelmaking raw-materials or finishing of semi-finished and other intermediate steel products is available to the Secretariat.

${ }^{25}$ For instance when the same target was tagged as both upstream and downstream or as both a steelmaker and one of either upstream or downstream.

${ }^{26}$ These are companies listed as Government (not listed) in the PublicStatus field of the Dealogic data set. This list is a broader than the state-owned enterprises tagged in the plant-level capacity data set. The Dealogic Government (not listed) group may include two types of companies not identified in the plantlevel data set. Firstly, it includes companies that are state-owned and involved in steel-related deals (in which one of either buyer or target is matched to the steelmaking capacity data set), but are not steelmakers and therefore have no match in the plant-level capacity data set. Secondly, Dealogic definition can also identify state-owned steelmaking companies that have changed name or ownership before 2019 and could not therefore be matched in the plant-level capacity data set. For this reason, the Dealogic-based tagging was included in the definition of state-owned cross-border investors when state-owned enterprises identified by Dealogic supported buyers matched in the plant-level capacity data set.

${ }^{27}$ A more sophisticated (or resource intensive) tagging methodology would be necessary to investigate more systematically the different types of deals along the steel value chain as well as different kinds of cross-border investors.

${ }^{28}$ Automation has been tried in the projects data set to match companies to the capacity data set, but it yielded reliably only around $10 \%$ of possible matches, with all other matches implemented manually. It is possible that the in-house algorithm used to automate the matching may be improved, but it is unlikely that manual checks on these tasks (tagging and matching) may be avoided for the foreseeable future. In the merger-and-acquisition data set, matches for OECD countries, China and India were carried out manually. Matches for non-OECD countries were automated, then complemented by manual matched and manual checks. Automated matches yielded $81.4 \%$ of the found matches. The remainder had to be matched or checked manually. 
${ }^{29}$ Automation has been tried in the projects data set to match companies to the capacity data set, but it yielded reliably only around $10 \%$ of possible matches, with all other matches implemented manually. It is possible that the in-house algorithm used to automate the matching may be improved, but it is unlikely that manual checks on these tasks (tagging and matching) may be avoided for the foreseeable future. In the merger-and-acquisition data set, matches for OECD countries, China and India were carried out manually. Matches for non-OECD countries were automated, then complemented by manual matched and manual checks. Automated matches yielded $81.4 \%$ of the found matches. The remainder had to be matched or checked manually.

${ }^{30}$ See above,

${ }^{31} \chi^{2}(1, \mathrm{~N}=3388)=22.623, \mathrm{p}=.000$.

32 This finding differs from findings in the preliminary version of the paper. Changes to the data set namely the exclusion of cancelled projects and the elimination of certain duplicates - led to a reversal of conclusions. It also exposes the precariousness of statistical conclusion achieved from working on small data sets.

${ }^{33}$ The relationship between mergers and acquisitions and capacity is analysed in the paper Market Consolidation and Steelmaking Capacity (DSTI/SC(2020)6/REV1).

${ }^{34}$ For the years 2000-13 the Secretariat's plant-level capacity data set, on which these numbers are based, does not allow for a systematic distinction between cross-border and domestic investment.

${ }^{35}$ The relationship between mergers and acquisitions and capacity is analysed in the paper Market Consolidation and Steelmaking Capacity (DSTI/SC(2020)6/REV1).

${ }^{36}$ For the years 2000-13 the Secretariat's plant-level capacity data set, on which these numbers are based, does not allow for a systematic distinction between cross-border and domestic investment.

${ }^{37}$ Information on cross-border investment in greenfield projects is limited to the years 2014 and 2017-19 (see 3.2 and 3.4).

${ }^{38}$ For the non-state group: median $=1.25 \mathrm{mmt}$. For the state-owned group: median $=3.8 \mathrm{mmt}$. MannWhitney $\mathrm{U}=1261, \mathrm{n} 1=190, \mathrm{n} 2=26, \mathrm{p}=.000$ two-tailed. Within each ownership category, differences in size between domestic investors and cross-border investors were not significant.

${ }^{39}$ For the non-state group: median $=1.25 \mathrm{mmt}$. For the state-owned group: median $=3.8 \mathrm{mmt}$. MannWhitney $\mathrm{U}=1261, \mathrm{n} 1=190, \mathrm{n} 2=26, \mathrm{p}=.000$ two-tailed. Within each ownership category, differences in size between domestic investors and cross-border investors were not significant.

${ }^{40}$ The size of investors is measured at the highest possible level of aggregation and for the year preceding the greenfield project investment announcement. This assumes that the ownership structure in that year was the same as in 2019. See section 3.3 for details on ownership history.

${ }^{41}$ Median size stood at $2.6 \mathrm{mmt}$ and $8.3 \mathrm{mmt}$ respectively for domestic and cross-border investors. MannWhitney $\mathrm{U}=891.0, \mathrm{n} 1=94, \mathrm{n} 2=33, \mathrm{p}=0.004$ two-tailed.

4218 of 19 multi-investor instances in the greenfield projects data set involved one cross-border investor and one domestic partner. The remaining instance saw a joint venture between two foreign entities. Minmetal and Hebei Xinwan Iron and Steel - respectively state-owned and non-state-owned Chinese companies - announced a 5.ommt steelmaking plant in Malaysia, which has not yet been commissioned.

${ }^{43}$ Some caution is necessary when interpreting these figures. As we have aggregated at the highest available level of ownership, it is possible that differences in size, and propensity to engage in more cross-border investment projects may reflect a different pace of consolidation intervened in the state-owned sector with respect to the non-state-owned sector since 2014. This may lead to commit projects to an investor retrospectively, for instance if an investor acquired a company that had previously invested abroad. It may also lead to omit projects retrospectively, for instance if an investor sold a company that had invested abroad before being sold.

${ }^{44}$ Some caution is necessary when interpreting these figures. As we have aggregated at the highest available level of ownership, it is possible that differences in size, and propensity to engage in more cross-border investment projects may reflect a different pace of consolidation intervened in the state-owned sector with respect to the non-state-owned sector since 2014. This may lead to commit projects to an investor retrospectively, for instance if an investor acquired a company that had previously invested abroad. It may also lead to omit projects retrospectively, for instance if an investor sold a company that had invested abroad before being sold.

${ }^{45}$ For regional groupings see Annex D.

${ }^{46}$ For cross-border deals and projects which took place in 2019, capacity estimates were used for the years 2020-2022, which consider the scheduled projects for which a commissioning date is known, as well as 
scheduled closures for which a closure date is known.

${ }^{47}$ As a lag exists between the announcement of the plan to build new steelmaking capacity and the commissioning of that capacity, there are two points in time against which changes in capacity may be considered: the time of the commissioning of the newly built capacity and the time of the announcement.

${ }^{48}$ As a lag exists between the announcement of the plan to build new steelmaking capacity and the commissioning of that capacity, there are two points in time against which changes in capacity may be considered: the time of the commissioning of the newly built capacity and the time of the announcement. ${ }^{49}$ Chinese capacity grew year-on-year in all years between 2000 and 2014, it declined in the years 20152018, then increased in 2019 (OECD, 2020[40] $)$.

${ }^{50}$ For a broader discussion of firm-level decisions and steelmaking capacity see DSTI/SC(2020)6/REV1.

${ }^{51}$ See section 3.3. The assumption implies that no steelmaking plant was acquired or sold in the period 2000-2019, as changes in the capacity stock of a firm via sales or acquisitions are not recorded in the data. The assumption is neutral with respect to capacity closures as it is unlikely that a closed asset will be sold on. It has however an impact on the attribution of the commissioning of new capacity. To clarify with an example: company A starts a steelmaking plant B in 1999. Company A then sells plant B to company C in 2005. The available data sets attributes ownership of plant B to company $C$ across the time series (20002019 for mergers and acquisition deals and 2014-2019 for greenfield projects), even though company C only acquired the plant after it was commissioned.

52 The relationship is statistically significant for the periods $t+2$ and $t+3$, though not for $t+1$.

${ }^{53}$ While the capacity figures take into account announced closures, these can be announced last minute making it possible that capacity will be lower in future years than what implied by the calculations used here.

${ }^{54}$ Growth was calculated as the compound-annual growth rates of up-to-three years before the investment. This represents the average recent-annual growth known to the investors at the time of the investment. For investment instances where three years were not available, all available years were included. Median growth in the non-state and state groups were $1.7 \%$ and $6.3 \%$ respectively. The distributions in the two groups differed significantly: Mann-Whitney $\mathrm{U}=29590, \mathrm{n} 1=1197, \mathrm{n} 2=66, \mathrm{p}=0.001$ two-tailed.

${ }^{55}$ Median growth in the non-state and state groups were $1.7 \%$ and $8.9 \%$ respectively. Mann-Whitney U = $6512, \mathrm{n} 1=1149, \mathrm{n} 2=21, \mathrm{p}=0.000$ two-tailed.

${ }^{56}$ Trade measures are only one component of the regulatory cost of exporting steel. Tariff and non-tariff measures are likely to constitute the bulk of such cost. However, a quantification of the impact of tariff and non-tariff measures by jurisdiction and over time is not available. Therefore, the counts of trade remedies were used at this stage to proxy increases in the cost of export for firms known to have invested abroad. It is also important to note that, at this stage, differences were checked at an aggregate level. We achieved this by matching trade remedies investigations to the jurisdiction of origin of cross-border investors. As investigation are targeted at firms, rather than jurisdictions, a more detailed analysis would require primary research, then matching between remedies and firms.

${ }^{57}$ Further research, based on firm-level trade remedies may shed a more nuanced light on the relationship between state ownership and the avoidance of trade remedies.

${ }^{58}$ More broadly, the concentration of state-owned cross-border investors in China, situates most considerations made in the paper firmly against the backdrop of the key Chinese policies affecting stateowned enterprises and cross-border investment. 



\section{References}

Barwick, P., M. Kalouptsidi and N. Zahur (2019), "China's Industrial Policy: An Empirical Evaluation”, NBER Working Paper, No. w26075, NBER, https://www.brown.edu/academics/economics/sites/brown.edu.academics.economics/files/ uploads/Yr19 Apr_Brown.pdf.

Bass, A. and S. Chakrabarty (2014), "Resource Security: Competition for Global Resources, Strategic Intent, and Governments as Owners", Journal of International Business Studies, Vol. 45/8, https://digitalcommons.unomaha.edu/mrktngmngmntfacpub/3 (accessed on 29 July 2020).

Boulter, J. (2018), “China's Supply-side Structural Reform”, Bulletin - Reserve Bank of Australia December, https://www.rba.gov.au/publications/bulletin/2018/dec/chinas-supply-sidestructural-reform.html (accessed on 3 August 2020).

Brainard, S. (1997), "An Empirical Assessment of the Proximity-Concentration Trade-off between Multinational Sales and Trade”, The American Economic Review, Vol. 87/4, pp. 520-544.

Bureau van Dijk (n.d.), Ultimate Owner identification, Orbis User Guide, https://help.bvdinfo.com/mergedProjects/68 EN/Ownership/ultimown new.htm (accessed on 25 July 2020).

Chakrabarti, A. (2001), "The Determinants of Foreign Direct Investments: Sensitivity Analyses of Cross-Country Regressions", Kyklos, Vol. 54/1, pp. 89-114, http://dx.doi.org/10.1111/14676435.00142.

Chen, L., D. Ding and R. Mano (2018), "China's Capacity Reduction Reform and Its Impact on Producer Prices", IMF Working Papers, No. 18/216, IMF, https://www.imf.org/en/Publications/WP/Issues/2018/o9/28/Chinas-Capacity-ReductionReform-and-Its-Impact-on-Producer-Prices-46223 (accessed on 28 July 2020).

Cuervo Cazurra, A. et al. (2014), "Governments as owners: State-owned multinational companies”, Journal of International Business Studies, Vol. 45/8, pp. 919-942, http://dx.doi.org/10.1057/jibs.2014.43.

Deng, P. (2004), "Outward investment by Chinese MNCs: Motivations and implications", Business Horizons, Vol. 47/3, pp. 8-16, http://dx.doi.org/10.1016/So007-6813(04)00023-0.

Feng, X., F. Lin and N. Sim (2019), "The effect of language on foreign direct investment”, Oxford Economics Papers, Vol. 71/1, pp. 269-291, http://dx.doi.org/10.1093/oep/gpyo34.

Garnaut, R., L. Song and Y. Yao (2006), "Impact and Significance of State-Owned Enterprise Restructuring in China”, The China Journal, Vol. 55, pp. 35-66, https://pdfs.semanticscholar.org/c4a7/259e832ce76ac1fff24819bac22afc2398c9.pdf. 
Gerring, J. (2007), Case Study Research, Cambridge University Press, Cambridge.

[39]

Gordon, J. and C. Milhaupt (2019), “China as a 'National Strategic Buyer': Towards a Multilateral Regime for Cross-Border M\&A”, Columbia Business Law Review, Vol. 2019/1, https://ssrn.com/abstract=3180250 (accessed on 30 March 2020).

Hatayama, H. and K. Tahara (2015), “Evaluating the sufficiency of Japan's mineral resource entitlements for supply risk mitigation”, Resources Policy, Vol. 44, pp. 72-80, http://dx.doi.org/10.1016/j.resourpol.2015.02.004.

Hebei Development and Reform Commission (2018), Notice on Issuing the "Implementation Plan for International Capacity Cooperation of Iron and Steel Enterprises in Hebei Province", http://hbdrc.hebei.gov.cn/web/web/zcfg_gfxwj/4028818b69053f5fo169085818eeod6c.htm (accessed on 3 November 2020).

Heilongjiang Province (2016), Notice of the General Office of the People's Government of Heilongjiang Province on Printing and Distributing the Implementation Plan for Heilongjiang Province to Promote International Cooperation in Production Capacity and Equipment Manufacturing, https://www.hlj.gov.cn/n200/2016/0823/c75-10788123.html (accessed on 3 November 2020).

IMF (2020), Fiscal Monitor - April 202O,

https://www.imf.org/en/Publications/FM/Issues/2020/04/06/fiscal-monitor-april-2020 (accessed on 28 July 2020).

KORES (n.d.), Overview- Businesses -Korea Resources Corporation, https://www.kores.or.kr/views/cms/eng/bu/bu01.jsp (accessed on 28 August 2020).

Kowalski, P. and K. Perepechay (2015), "International Trade and Investment by State Enterprises”, OECD Trade Policy Papers, No. 184, OECD Publishing, Paris, https://dx.doi.org/10.1787/5jrtcr9x6c48-en.

Kowalski, P. and D. Rabaioli (2017), "Bringing together international trade and investment perspectives on state enterprises”, OECD Trade Policy Papers, No. 201, OECD Publishing, Paris, https://dx.doi.org/10.1787/e4019e87-en.

Lehmann, F. and A. Tavares-Lehmann (2014), A comparative study of mergers and acquisitions by privately- and state-owned enterprises, OECD, https://one.oecd.org/\#/document/DAF/INV/WD(2015)4/ANN1/en? k=l1r373.

Liaoning Provincial Industry and Information Department (2016), Implementation Opinions of [16] the People's Government of Liaoning Province on Promoting Industrial Supply-side Structural Reform, http://gxt.ln.gov.cn/zwgk_123432/zdgz_123445/ctcyzxsj/201710/t20171026_3090892.html (accessed on 4 November 2020).

Mattera, G. (2019), Exploring the linkages between steelmaking capacity, government [33] interventions and trade. Step1: Steelmaking capacity changes and trade dynamics, OECD, Paris, https://one.oecd.org/document/DSTI/SC(2019)14/en/pdf. 
Mattera, G. and F. Silva (2018), "State enterprises in the steel sector", OECD Science, Technology [2] and Industry Policy Papers, No. 53, OECD, Paris, http://www.oecd.org/officialdocuments/publicdisplaydocumentpdf/?cote=DSTI/SC(2017)10 $\not$ FINAL\&docLanguage $=$ En.

Molnar, M. and J. Lu (2019), "State-owned firms behind China's corporate debt”, OECD Economics Department Working Papers, No. 1536, OECD, Paris, https://www.oecd.org/officialdocuments/publicdisplaydocumentpdf/?cote=ECO/WKP(2019 25\&docLanguage $=$ En $($ accessed on 30 July 2020)

OECD (2020), LATEST DEVELOPMENTS IN STEELMAKING CAPACITY 2020, OECD, Paris, http://www.oecd.org/industry/ind/latest-developments-in-steelmaking-capacity-2020.pdf (accessed on 24 July 2020).

OECD (2020), STATE-OWNED ENTERPRISES IN THE SHIPBUILDING SECTOR, OECD, Paris, https://one.oecd.org/document/C/WP6(2020)5/en/pdf (accessed on 15 April 2020).

OECD (2019), Cross-border Investment by State Enterprises in the Steel Sector, OECD, Paris, https://one.oecd.org/document/DSTI/SC(2019)15/en.

OECD (2019), Data preparation for use on international investment analysis using ORBIS, OECD, Paris.

OECD (2019), "Measuring distortions in international markets: the aluminium value chain", OECD Trade Policy Papers, No. 218, OECD Publishing, Paris, https://dx.doi.org/10.1787/c82911ab-en.

OECD (2019), "Measuring distortions in international markets: The semiconductor value chain", OECD Trade Policy Papers, No. 234, OECD Publishing, Paris, https://dx.doi.org/10.1787/8fe4491d-en.

OECD (2016), State-Owned Enterprises as Global Competitors: A Challenge or an Opportunity?, OECD Publishing, Paris, https://dx.doi.org/10.1787/9789264262096-en.

OECD (2015), OECD Guidelines on Corporate Governance of State-Owned Enterprises, 2015 Edition, OECD Publishing, Paris, https://dx.doi.org/10.1787/9789264244160-en.

OECD (2014), Database on National Practices and Regulations with Repsoect to State Enterprises, OECD, https://qdd.oecd.org/subject.aspx?Subject=8F22EF7D-B780-4570A4B1-7EoCB3AD7E04.

Oecd (2008), OECD Investment Policy Reviews - China 2008.

Qatari General Secretariat for Development Planning (2008), Qatar National Vision 2030, General Secretariat For Development Planning, Doha, http://www.planning.gov.qa (accessed on 28 August 2020).

Ren, M. and R. Jack (2015), “China's 'Steel Hunger': A Comparative Analysis of SOE and NSOE Internationalization Motivations and Attitudes towards Risk", Contemporary Management Research, http://dx.doi.org/10.7903/cmr.12484.

Song, L. (2018), "State-owned enterprise reform in China: Past, present and prospects", in Song, L., R. Garnaut and C. Fang (eds.), China's 40 Years of Reform and Development, ANU Press, http://www.jstor.org/stable/j.ctv5cgbnk.27. 
Tham, S. and W. Yeoh (2020), “Chinese Steel Investments in ASEAN”, Perspective, Vol. 2020/50, https://www.iseas.edu.sg/wpcontent/uploads/2020/03/ISEAS_Perspective_2020_50.pdf (accessed on 30 July 2020).

Watanabe, M. (2020), Competitive Neutrality of State-owned Enterprises in China's Steel Industry: Causal Inference on the Impacts of Subsidies, https://www.rieti.go.jp/en/ (accessed on 28 February 2020).

Yeoh, W. (2020), The ASEAN Steel Industry in 2019 and Overcapacity Issues, South East Asia [37] Iron and Steel Institute, http://steelforum.org/stakeholders/gfsec-july-2020-seaisi.pdf (accessed on 27 July 2020). 


\section{Annex A. The projects data set}

The projects data set contains the list of active steelmaking investment projects compiled by the Secretariat in 2014, 2017, 2018 and 2019. The list was consolidated eliminating duplicates and reconciling information that had changed over time. As noted in section 3.4, projects are understood as publicly stated intentions to build new steelmaking capacity. Information attached to such public statements (for instance about which technology to build, how much capacity to build and when to build) is prone to changing over time. Tagging of the state-enterprise status, and matching to plants and companies present in the plant-level-capacity data set were also carried out.

Entries in the data set are project-investor unique pairings. In addition, when available, the projects data set contains data on:

- location,

- steelmaking technology,

- capacity,

- capex,

- phase of expansion,

- tagging of state-enterprise status at the $25 \%$ and at $50 \%$ equity ownership thresholds,

- matching to the plant-level-capacity data set.

The data set contains 469 observations, corresponding to 469 project-investor unique combinations. There are 391 unique projects in 335 unique sites, as the construction of steelmaking capacity is often planned in phases. Overall projects in the data set are directed at 61 economies and originated in 60 (only partially overlapping) economies. There were 298 unique ultimate investors in the data set.

In total, matches to the plant-level-capacity data set were retrieved for 349 entries (equivalent to 287 unique projects). At the company level, matches were for 139 unique companies and at the group level, matches were possible for 52 observations equivalent to 23 unique companies. ${ }^{1}$

Of the 391 unique projects, capacity was known for 379 . The median capacity for this subset stood at $1.0 \mathrm{mmt}$.

In 107 of the 405 projects at least one of the investors was foreign. For 18 projects, not sufficient information was found to determine the jurisdiction of origin of the investor. The remaining projects were classed as domestic. The 107 cross-border deals where directed at 36 economies and originated from 41 . In the cross-border subset of data, matches were found for 35 entries ( 28 unique projects). At the company level matches were possible in 35 instances (20 unique companies) and at the group level, matches were possible for 11 observations ( 6 unique companies). The number of matches increased across the board following an increase in coverage of the OECD capacity database. 
Of the 104 unique cross-border projects, capacity was known for 100 projects. The median capacity for this subset stood at $1.4 \mathrm{mmt}$.

- location,

- steelmaking technology,

- capacity,

- capex,

- phase of expansion,

- tagging of state-enterprise status at the $25 \%$ and at $50 \%$ equity ownership thresholds,

- matching to the plant-level-capacity data set.

The data set contains 469 observations, corresponding to 469 project-investor unique combinations. There are 391 unique projects in 335 unique sites, as the construction of steelmaking capacity is often planned in phases. Overall projects in the data set are directed at 61 economies and originated in 60 (only partially overlapping) economies. There were 298 unique ultimate investors in the data set.

In total, matches to the plant-level-capacity data set were retrieved for 349 entries (equivalent to 287 unique projects). At the company level, matches were for 139 unique companies and at the group level, matches were possible for 52 observations equivalent to 23 unique companies. $^{2}$

Of the 391 unique projects, capacity was known for 379 . The median capacity for this subset stood at $1.0 \mathrm{mmt}$.

In 107 of the 405 projects at least one of the investors was foreign. For 18 projects, not sufficient information was found to determine the jurisdiction of origin of the investor. The remaining projects were classed as domestic. The 107 cross-border deals where directed at 36 economies and originated from 41. In the cross-border subset of data, matches were found for 35 entries ( 28 unique projects). At the company level matches were possible in 35 instances (20 unique companies) and at the group level, matches were possible for 11 observations (6 unique companies).

Of the 104 unique cross-border projects, capacity was known for 100 projects. The median capacity for this subset stood at $1.4 \mathrm{mmt}$. 


\section{4 | CROSS-BORDER INVESTMENT BY STATE-OWNED ENTERPRISES}

Table A.1. Summary of projects

\begin{tabular}{l|r|r|r}
\hline & Projects data set & $\begin{array}{c}\text { Matched in the plant- } \\
\text { level-capacity data set }\end{array}$ & $\begin{array}{c}\text { State-enterprise } \\
\text { status manually } \\
\text { tagged }\end{array}$ \\
\hline Number of observations & 469 & 349 & \\
\hline Number of unique plants & 335 & 162 & 139 \\
\hline Number of unique companies & 298 & 58 & \\
\hline Number of unique jurisdictions & 70 & & \\
\hline Coverage of crude-steel capacity & $100 \%$ & & \\
\hline Number of jurisdictions not-yet covered & 0 & & \\
\hline Estimated number of companies outstanding* & 56 & 28 & \\
\hline $\begin{array}{l}\text { Number of state-owned enterprises at } 50 \% \text { equity } \\
\text { ownership }\end{array}$ & & & 43 \\
\hline
\end{tabular}

Note: i) the number of jurisdictions not-yet covered is the number of jurisdiction listed in the OECD capacity data set for which plant-level data are not yet available minus the number of jurisdictions in the plant-levelcapacity data set; ii) counts of state-owned enterprises at different levels of equity ownership are counts of unique companies; iii) counts of state-owned enterprises at $10 \%$ equity ownership are lifted directly from Orbis and do not represent a systematic application of that threshold to the entire data set; iv) although automatically retrieved, the tagging came from the plant-level-capacity data set where it had been coded manually.

Source: OECD

${ }^{1}$ As projects are speculative, they may still not included in the capacity data set. However, if an investor already owned capacity at sites other than the site of the project, a match was made at the investor level. ${ }^{2}$ As projects are speculative, they may still not included in the capacity data set. However, if an investor already owned capacity at sites other than the site of the project, a match was made at the investor level. 



\section{Annex B. The merger-and-acquisition data set}

The Dealogic data set comprises data on mergers and acquisitions that have occurred in the steel sector between 2000 and the first half of 2019. When available, the data set includes data on:

- actors involved in the deal (buyer, seller, target),

- jurisdiction of origin of the actors,

- some economic performance indicators of the actors at the time of the deal,

- stakes acquired with the deal,

- value of the deal in USD million,

- matching to the plant-level-capacity data set,

- Dealogic's own tagging for state-owned enterprises.

For the purpose of the present work, the data set has been reduced to include only the deals that meet all of the following conditions i) have both a buyer and a target; ii) the buyer and the target are domiciled in two different jurisdictions iii) at least one of the actors has a match in the OECD capacity database.

This subset of the data contains 3273 entries, containing 1175 deals for 1315 buyers (of which 532 unique) and 1213 targets (of which 941 unique companies). In total, there are 1664 unique companies and matches to the capacity data set were found for 245 of them. For 660 deals the value was available. The median value stood at USD39.6 million (in real 2010 terms). 
Table B.1. Summary of cross-border mergers and acquisitions

\begin{tabular}{l|r|r|r}
\hline & $\begin{array}{c}\text { Merger-and- } \\
\text { acquisition data set }\end{array}$ & $\begin{array}{c}\text { Matched in the plant- } \\
\text { level-capacity data set }\end{array}$ & $\begin{array}{c}\text { Manually } \\
\text { tagged }\end{array}$ \\
\hline Number of observations & 3273 & & \\
\hline Number of unique deals & 1175 & 231 & 162 \\
\hline Number of unique companies & 1664 & 72 & \\
\hline Number of unique jurisdictions & 92 & & \\
\hline Share of crude-steel capacity in covered jurisdictions & $96.1 \%$ & & \\
\hline Number of jurisdictions not-yet covered & 20 & 20 & \\
\hline Estimated number of companies outstanding & 81 & & 12 \\
\hline $\begin{array}{l}\text { Number of state-owned enterprises at 50\% equity } \\
\text { ownership }\end{array}$ & & & \\
\hline
\end{tabular}

Note: i) the subset of data includes only deals for which at least one target and one buyer is known, and for which buyer(s) and target(s) belong to different jurisdictions. It does not include sellers; ii) the number of jurisdictions not-yet covered is the number of either jurisdictions listed in the OECD capacity data set for which plant-level data are not yet available or jurisdictions where firms that have engaged in cross-border investment in the steel sector do not have steelmaking capacity; iii)Dealogic has more state-owned enterprises than the plant-level-capacity data set as actors involved in steel-relevant deals may not be steelmakers.

Source: Dealogic, OECD 


\section{Annex C. The plant-level-capacity data set}

The data set contains data on crude steel capacity at the most granular level available. ${ }^{1}$ The plant-level-capacity data set is a live document, continuously updated with the latest available information. As of 14 October 2020, it contained 2623 entries, for a count of 1 962 unique steelmaking plants and 1605 unique companies in 105 economies.

Associated to capacity, the data set contains, when available, information on:

- location,

- steelmaking technology,

- capex,

- owner company and its jurisdiction of domicile (up to three owners),

- owner group and its jurisdiction of domicile,

- tagging of state-enterprise status at the $50 \%$ equity threshold,

- information of the operating status of a plant or equipment, whichever is available,

- matching to Orbis companies identifiers,

- start year,

- closure year.

Of the 1605 unique companies, 147 were tagged as state-owned enterprises at the $50 \%$ equity ownership threshold. 1156 as not state-owned at the 50\% threshold. The remaining 302 could not be tagged for lack of sufficient information or could not be tagged in time for this project.

The data set contains data on crude steel capacity at the most granular level available. ${ }^{2}$ The plant-level-capacity data set is a live document, continuously updated with the latest available information. As of 14 October 2020, it contained 2623 entries, for a count of 1 962 unique steelmaking plants and 1605 unique companies in 105 economies.

Associated to capacity, the data set contains, when available, information on:

- location,

- steelmaking technology,

- capex,

- owner company and its jurisdiction of domicile (up to three owners),

- owner group and its jurisdiction of domicile,

- tagging of state-enterprise status at the $50 \%$ equity threshold,

- information of the operating status of a plant or equipment, whichever is available,

- matching to Orbis companies identifiers, 
- $\quad$ start year,

- closure year.

Of the 1605 unique companies, 147 were tagged as state-owned enterprises at the $50 \%$ equity ownership threshold. 1156 as not state-owned at the $50 \%$ threshold. The remaining 302 could not be tagged for lack of sufficient information or could not be tagged in time for this project.

More information on the latest capacity updates can be found in the latest capacity document DSTI/SC(2020)10 and an in-depth description of the data set DSTI/SC(2020)5. Those documents describe the latest version of the capacity data set, and are the go-toreference. The summary provided here refers to the data set as of end of June 2020, as that vintage was used in this work. As all major cross-border investors were already included in the vintage, it is unlikely that difference may radically affect the summary of crossborder investment presented in this paper.

\section{Table C.1 Summary of plant-level-capacity}

\begin{tabular}{l|r|r}
\hline & \multicolumn{1}{|c}{$\begin{array}{c}\text { Plant-level-capacity } \\
\text { data set }\end{array}$} & \multicolumn{1}{|c}{$\begin{array}{c}\text { Manually } \\
\text { tagged }\end{array}$} \\
\hline Number of observations & 2623 & \\
\hline Number of unique plants & 1962 & 995 \\
\hline Number of unique companies & 1605 & \\
\hline Number of unique jurisdictions & 105 & \\
\hline Share of crude-steel capacity in covered jurisdictions & $99.5 \%$ & \\
\hline Number of jurisdictions not-yet covered & 26 & 134 \\
\hline Number of state-owned enterprises at 50\% equity & 147 & \\
Ownership & & \\
\hline
\end{tabular}

Note: i) the number of jurisdictions not-yet covered is the number of jurisdiction listed in the OECD capacity data set for which plant-level data are not yet available; ii) the share of total capacity accounted for by the plantlevel-capacity data set refers to the year 2019; iii) counts of state-owned enterprises at different levels of equity ownership are counts of unique companies.

Source: OECD

${ }^{1}$ This may be a steelmaking plant (or production site) a set of pieces of steelmaking equipment (for instance all EAF furnaces in a steelmaking plant) or a piece of steelmaking equipment (for instance an individual EAF in a steelmaking plant)

${ }^{2}$ This may be a steelmaking plant (or production site) a set of pieces of steelmaking equipment (for instance all EAF furnaces in a steelmaking plant) or a piece of steelmaking equipment (for instance an individual EAF in a steelmaking plant) 


\section{Annex D. Regions}

Regions are as follows:

OECD and the EU contain their members as of end of 2019.

CIS: Russia, Kazakhstan, Moldova, Uzbekistan;

Middle East: United Arab Emirates, Iran, Iraq, Oman, Saudi Arabia;

North Africa: Algeria, Egypt, Morocco, Mauritania;

Other Central America: Bahamas, Costa Rica, Dominican Republic, Panama, Trinidad and Tobago;

Other Central Asia: Georgia, Mongolia;

Oher East Asia: Hong Kong (China), Chinese Taipei;

Other EU: Bulgaria, Cyprus ${ }^{1}$, Croatia, Malta Romania;

Other Europe: Gibraltar, Montenegro, North Macedonia, Serbia, Ukraine;

Other South America: Argentina, Bolivia, Brazil, Colombia, Ecuador, Peru, Paraguay, Uruguay, Venezuela;

South Asia: Afghanistan, Bangladesh, Bhutan, India, Mauritius, Pakistan;

Southeast Asia: Indonesia, Cambodia, Myanmar, Malaysia, Philippines, Singapore, Thailand, Viet Nam;

South Saharan Africa: Cameroon, Ethiopia, Kenya, Mozambique, Nigeria, Tanzania, South Africa, Zimbabwe.

\footnotetext{
${ }^{1}$ Note by Turkey: The information in this document with reference to "Cyprus" relates to the southern part of the Island. There is no single authority representing both Turkish and Greek Cypriot people on the Island. Turkey recognizes the Turkish Republic of Northern Cyprus (TRNC). Until a lasting and equitable solution is found within the context of United Nations, Turkey shall preserve its position concerning the "Cyprus" issue.

Note by all the European Union Member States of the OECD and the European Union: The Republic of Cyprus is recognized by all members of the United Nations with the exception of Turkey. The information in this document relates to the area under the effective control of the Government of the Republic of Cyprus.
} 